AperTO - Archivio Istituzionale Open Access dell'Università di Torino

National social spaces as adjustment variables in the EMU: A critical legal appraisal

This is a pre print version of the following article:

Original Citation:

Availability:

This version is available http://hdl.handle.net/2318/1672024

since 2021-03-08T11:17:46Z

Published version:

DOI:10.1111/eulj.12278

Terms of use:

Open Access

Anyone can freely access the full text of works made available as "Open Access". Works made available under a Creative Commons license can be used according to the terms and conditions of said license. Use of all other works requires consent of the right holder (author or publisher) if not exempted from copyright protection by the applicable law. 


\title{
National Social Spaces as Adjustment Variables in the EMU: A Critical Legal Appraisal
}

\author{
Francesco Costamagna*
}

\begin{abstract}
The article critically engages with the reconfiguration of the role and status of national social spaces within the EU constitutional fabric after the reform of European economic governance. Its main contention is that these reforms have converted national social spaces into adjustment variables whose main function is to contribute to the pursuit of EMU-related objectives. This transformation alters the balance between the economic and the social dimension in the EU legal order, deforming one of the defining traits of its constitutional identity.
\end{abstract}

\section{Introduction}

National social spaces are the ensemble of national welfare systems and labour market policies characterized by distinct endowments of schemes and institutions, as well as by different logics and backgrounds. ${ }^{1}$ They are a key component of the European socio-economic architecture. Due to the lack of legal competences, financial resources and democratic credentials at supranational level to elaborate a substantive social policy, they are the only loci where ideate and carry out meaningful redistributive activities to "combat social exclusion and discrimination, $[\ldots]$ promote social justice" and "social cohesion", as provided for by Article 3 TEU.

However, one of the most visible, and troubling, consequences of the Eurocrisis is the increasing inability of national social spaces to cope with the dramatic rise of poverty, social exclusion and economic inequality ${ }^{2}$ all over Europe and, in particular, in a number of southern States. ${ }^{3}$ This has negatively affected public opinion's perception of the European integration process, since the EU is often singled out as the main culprit of the situation. On the one hand, this account, which has been eagerly embraced by blame-avoiding national politicians, offers a skewed picture of the reality, overemphasising the role played by supranational institutions in the process. On the other hand, it is hard to deny that the response to the crisis, and the ensuing reform of surveillance and financial assistance mechanisms, has had a bearing on the situation. Indeed, these mechanisms have been mostly modelled around certain core neoliberal policy prescriptions, such as budgetary austerity or the flexibilisation of labour markets

\footnotetext{
${ }^{*}$ University of Turin and Collegio Carlo Alberto. I would like to thank Matthias Goldmann, Agustin Menéndez, Alberto Miglio, Stefano Montaldo, Stefano Saluzzo, Harm Schepel, Andrea Spagnolo and Anna Viterbo for their insightful comments on earlier versions of this work. The article has been written in the context of the REScEU project (Reconciling Economic and Social Europe, www.resceu.eu), funded by the European Research Council (grant no. 340534).

${ }^{1}$ The notion and the definition are borrowed from M. Ferrera, 'Social Europe and its Components in the Midst of the Crisis', (2014) 37 West European Politics 825, 827-828.

2 See the staggering data published in the World Inequality Report 2018 (available at http://wir2018.wid.world/files/download/wir2018-full-report-english.pdf)

${ }^{3}$ See recently, OECD, The Socio-Economic Divide in Europe. Background Report, 26 January 2017, 7-11. It is worth highlighting that, especially in peripheral countries, the crisis just deteriorated an economic situation that has been mostly characterized by slow, or even negative, economic growth and high unemployment rates since the 1980 s.
} 
and the repression of wage demands, which severely reduce the capacity of national social spaces to perform their redistributive functions.

The article critically engages with the reconfiguration of the role and status of national social spaces within the EU constitutional fabric after the reform of European economic governance. Its main contention is that these reforms have converted national social spaces into adjustment variables whose main function is to contribute to the pursuit of EMU-related objectives. This transformation alters the balance between the economic and the social dimension in the EU legal order, deforming one of the defining traits of its constitutional identity. ${ }^{4}$ The analysis builds upon the burgeoning legal literature $^{5}$ - and even meta-literature ${ }^{6}$ - on EU constitutional transformations in the aftermath of the Eurozone crisis. It does so by focusing on an aspect - the status of national social spaces in the EMU - that is still under researched, and by connecting it with other lines of inquiry, such as the one on the demise of the rule of law in Europe, which have received far more attention. Moreover, the analysis draws on political science works concerned with the role of national social spaces in the EU-building process, as well as with the tensions generated by the encounter between the two. ${ }^{7}$

More in detail, the article first tracks the trajectory of national social spaces' role and status within the European integration process, from the so-called 'original compromise' enshrined in the Treaty of Rome to the Lisbon Treaty's attempt to reconcile the 'economic' and the 'social' within the supranational legal framework. The analysis then focuses on the early steps of the EMU and their potential impact upon national social spaces' scope and functions. The third part of the article looks at the reform of European economic governance, starting from the strengthening of economic and social policies coordination mechanisms. The main point here is that, at least in its early cycles, the European Semester contributed much to the subordination of national social spaces to the strengthening of the EMU, paying scant attention to safeguarding their capacity to pursue core social objectives. This part of the analysis also considers the efforts to imbue the Semester with greater social sensitivity, claiming that the attempts to move away from the original one-sided approach are certainly promising, but still too limited. Lastly, the analysis turns to financial assistance programmes and the use of the conditionality policy therein. The analysis shows that, in this context, the above-described transformative process reached its apex, treating national social spaces just as a cost to be reduced or as a factor that must contribute to making the State concerned more competitive. The article takes a critical stance towards this approach and its implementing strategy centred on the creation of "empty constitutional spaces" 8 in order to insulate technocratic governance from political and legal responsibility. Likewise, the article criticizes some recent attempts to inject greater social sensitivity into both the procedure and the substance of structural adjustment programmes,

\footnotetext{
${ }^{4}$ Claire Kilpatrick described this drift as a form of "displacement of Social Europe". See C.Kilpatrick, 'The Displacement of Social Europe: A Productive Lens of Inquiry', (2018) 14 European Constitutional Law Review 62.

${ }^{5}$ See, ex multis, M. Ioannidis, 'Europe's New Transformations: How the EU Economic Constitution Changed During the Eurozone Crisis', (2016) 53 Common Market Law Review 1237; F. De Witte and M. Dawson, 'From Balance to Conflict: A New Constitution for the EU', (2015) 22 European Law Journal 204.

${ }^{6}$ T. Beuker, Legal Writing(s) on the Eurozone Crisis, EUI Working Paper 2015/11; G. Martinico, EU Crisis and Constitutional Mutations: A Review Article, (2014) STALS Research paper No. 3;

7 See recently M. Ferrera, 'The JCMS Annual Lecture: National Welfare States and European Integration: In Search of a "Virtuous Nesting", (2009) 47 Journal of Common Market Studies 219.

8 A.J. Menéndez Menéndez, 'The Crisis and the European Crises: From Social and Democratic Rechtsstaat to the Consolidating State of (Pseudo-)technocratic Governance', (2017) 44 Journal of Law and Society 56, 75.
} 
showing their manifest inadequacy in restoring balance between the pursuit of EMUrelated objectives and the safeguarding of national social spaces.

\section{National social spaces within the European integration process: the trajectory from Rome to Lisbon}

2.1 The original compromise: the establishment of the internal market as a way to strengthen national social spaces

The consolidation of territorially bounded social spaces in Europe has been described as the last phase in the development of the European system of nation States. ${ }^{9}$ An important step in this direction was taken at the end of the nineteenth century, when a number of States ${ }^{10}$ introduced compulsory social insurance mechanisms. ${ }^{11}$ These programmes were strengthened after World War I and, in some countries, connected with a more intrusive public regulation of labour relations, so to contain mounting social tensions and avoid them developing into fully-fledged revolutionary movements. ${ }^{12}$ The post-World War II settlement cemented the place of welfare and labour policies at the core of European States' constitutional identity. In the process, national social systems evolved from both a quantitative and, even more importantly, a qualitative perspective, going through their 'golden age'. ${ }^{13}$ As for the quantitative dimension, the growth of social expenditure is a good proxy in this regard: European States' social budgets went from $5 \%$ in 1940 to almost $30 \%$ of GDP in $1970 .{ }^{14}$ Coming to the qualitative dimension, welfare and labour policies became the centrepiece of post-war European States' constitutional architecture, as duly reflected in the newly-adopted constitutions. ${ }^{15}$ In this context, social policy was no longer just a tool to address specific concerns, such as the relief of destitution or the maintenance of public order. The receipt of public welfare ceased to be stigma and a barrier to political participation, ${ }^{16}$ becoming a prerequisite for the effective exercise of citizenship rights. To this end, national welfare states extended their coverage, engaging in wide-scale redistributive efforts targeting not just the poor or specific typologies of risks. Post-war welfare states,

${ }^{9}$ S. Bartolini, Restructuring Europe (Oxford University Press, 2005).

${ }^{10}$ Such as Austria (1887), Norway (1894), Finland (1895), Germany (1883) and Italy (1898).

11 M. Ferrera, The Boundaries of Welfare: European Integration and the New Spatial Politics of Social Protection (Oxford University Press, 2005), 54, points out that '[s]ocial insurance was a real institutional breakthrough in the history of the European nation state'.

12 This is the one of the reasons why these measures and the overall logic of the welfare state attracted severe criticism from the left. In the Address of the Central Committee to the Communist League (London, 1850), Marx and Engels pointed out that "the democratic petty bourgeois want better wages and security for the workers, and hope to achieve this by an extension of state employment and by welfare measures; in short, they hope to bribe the workers with a more or less disguised form of alms and to break their revolutionary strength by temporarily rendering their situation tolerable".

${ }^{13}$ Ferrera, above, n. 11, at 77.

${ }^{14}$ S. Pierson, 'Origins and Development of the Welfare State 1880-1975', in S. Pierson (ed.), Beyond the Welfare State? The New Political Economy of Welfare (Polity Press, 1991), 108-109.

15 The example of the Italian Constitution of 1948 stands out in this regard. Lelio Basso points out that the commitment toward the social development of the society represented the essence of the new democratic state, as well reflected in Article 3 of the Constitution. This provision reads as follows: "[è] compito della Repubblica rimuovere gli ostacoli di ordine economico e sociale, che, limitando di fatto la libertà e l'eguaglianza dei cittadini, impediscono il pieno sviluppo della persona umana e l'effettiva partecipazione di tutti i lavoratori all'organizzazione politica, economica e sociale del Paese". See L. Basso, Il Principe senza scettro. Democrazia e sovranità popolare nella Costituzione e nella realtà italiana (Feltrinelli, 1958), 133.

${ }^{16}$ For instance, the Belgian law of 1894 universalising the suffrage explicitly excluded "les mendiants et vagabonds internes dans une maison de refuge [...] par decision des juges de paix". 
although quite different one another, ${ }^{17}$ moved from partial and selective provision of social services to a comprehensive "cradle-to-grave" coverage of the population. The State played a key role in this process, progressively displacing the private provision of welfare and setting up a general institutional framework that shaped educational and employment opportunities. Post-war welfare states were conceived as collective undertakings based on a political decision rather than as an aggregate of individual rights. ${ }^{18}$ These comprehensive redistributive efforts mostly benefited the middle class, ${ }^{19}$ facilitating the emergence of a broad majoritarian class ${ }^{20}$ and, by so doing, contributing to invigorate European States' democratic credentials.

The evolution described above helps to understand why European States were keen on guarding their 'social sovereignty' against any external intrusion. These concerns were very much present during the negotiations leading to the adoption of the Treaty of Rome of 1957 that established the European Economic Community (EEC). After an intense debate, the final decision was to exclude almost any possibility for the EEC to intervene in the social field. ${ }^{21}$ The only exception was the conferral of those social powers necessary to ensure the functioning of the internal market. For instance, the Council was entitled to adopt measures for the coordination of national social security systems to facilitate the free movement of workers. ${ }^{22}$ This led to a decoupling of the social and the economic spheres, leaving the former in Member States' hands, while opening the latter to the intervention of the then EEC.

Some commentators depicted the abstentionist approach embodied in the Treaty of Rome as the by-product of the founding fathers' 'social frigidity' ${ }^{23}$ But a more careful analysis of the situation suggests the opposite: the choice to leave the social sphere beyond the reach of supranational institutions was meant to preserve Member States' capacity to exercise their social prerogatives. ${ }^{24}$ Furthermore, the compromise rested on the assumption that the economic benefits deriving from the establishment of an integrated market would increase the redistributive capacity of national authorities, thereby contributing to the levelling up of social standards. ${ }^{25}$ In turn, ensuring that market forces were constrained in such a way as to invigorate national social spaces constituted the "constitutional-supranational raison d'être". ${ }^{26}$ As pointedly observed by Giubboni, "[t]he institutional framework conceived by the founding fathers was [...] totally in line with the cornerstones of embedded liberalism: the gradual institutionalization [...] of free market principles at transnational level would be based 1990).

17 See G. Esping-Andrsen, The Three Worlds of Welfare Capitalism (Princeton University Press,

${ }^{18}$ R. Titmuss, 'Welfare 'Rights”, Law and Discretion', (1971) 42 The Political Quarterly 113. More generally, see T. Judt, Postwar. The History of Europe Since 1945 (The Penguin Press, 2005), 360-389.

${ }^{19}$ R. Goodin and J. Le Grand, Not Only the Poor. The Middle Classes and the Welfare State (Unwin Hyman, 1987).

${ }^{20}$ S. Mau, Inequality, Marketization and the Majority Class: Why Did the European Middle-Classes Accept Neoliberalism? (Palgrave, 2015), 1-9.

${ }^{21}$ F. Scharpf, 'The European Social Model: Coping with the Challenges of Diversity', (2002) 40 Journal of Common Market Studies 645, 645-648.

${ }^{22}$ Article 51 of the Treaty Establishing the European Economic Community, Rome, 25 March 1957.

23 G.F. Mancini, 'Principi fondamentali di diritto del lavoro nell'ordinamento delle Comunità europee', in Il lavoro nel diritto comunitario e l'ordinamento italiano (CEDAM, 1988), 33.

${ }^{24}$ See Report by a Group of ILO Experts (1956), Social Aspects of European Economic Co-operation, Geneva: International Labour Office, para. 210.

25 S. Giubboni, Social Rights and Market Freedoms in the European Constitution. A Labour Law Perspective (Cambridge University Press, 2006), 55.

${ }^{26}$ C. Joerges and F. Rödl, 'Informal Politics, Formalized Law and the "Social Deficit" of European Integration: Reflections after the Judgments of the ECJ in Viking and Laval', (2009) 15 European Law Journal 1, 5. 
on the guarantee, non less secure for being implicit, of the preservation of strong and deeply rooted national welfare-state systems". ${ }^{27}$

\subsection{The crisis of the original compromise and the infiltration of internal market law} into national social spaces

The compromise remained stable for little more than a decade. Then it began to falter due to a dramatic change in the economic and political background. The deterioration of the economic situation, due to the oil crises of 1973 and 1979, and the failure of the expansionary policies adopted by some States ${ }^{28}$ to cope with it, dealt the final blow to Keynesianism, ${ }^{29}$ in any of its varieties. ${ }^{30}$ At the end of the 1970 s the neoliberal political project materialized and consolidated worldwide, ${ }^{31}$ thanks to the support of conservatives and social democrats alike. ${ }^{32}$ The new political project aimed at emancipating free markets from politics and society at large. Market liberalization was largely seen as the only remedy for the economic crises of the 1970s and, consequently, it returned to the top of political agendas. ${ }^{33}$

This shift reverberated in the EU legal order, taking the form of a strong push toward completion of the internal market. ${ }^{34}$ In 1985 the Commission adopted a White Paper ${ }^{35}$ which, despite claiming to be only "a programme and a timetable" 36 for the achieving such objective, in reality it set in motion a momentous transformation of the European integration process. ${ }^{37}$ The White Paper identified the elimination of non-tariff barriers as the main step to be taken toward the creation of a fully integrated market, especially after the abolition of customs duties between Member States. The Single European Act provided supranational institutions with the legal means to pursue this

${ }^{27}$ Giubboni, above, n. 25, at 17 (emphasis in the original). See also F. De Witte, 'The Architecture of EU's Social Market Economy', in P. Koutrakos and J. Snell (eds), Research Handbook on the Law of the EU's Internal Market (Edward Elgar, 2016), 121.

28 This was the case of France, for instance: see J. Sachs and C. Wyplosz, 'The Economic Consequences of President Mitterand', (1986) 2 Economic Policy 262.

29 W. Sandholtz, 'Choosing Union: Monetary Politics and Maastricht', (1993) 47 International Organizations 1, 6-7.

${ }^{30}$ Coddington distinguished between 3 main approaches: the fundamentalist, the hydraulic and the reconstituted reductionist: see A. Coddington, 'Keynesian Economics: The Search for First Principles', (1976) 14 Journal of Economic Literature 1258.

${ }^{31}$ An important moment of this ideational evolution was the publication by the OECD of the so-called McCracken Report (see P. McCracken, Towards Full Employment and Price Stability, (OECD, 1977)). For a critical analysis of the Report see R. Kehoane, 'Economics, Inflation, and the Role of the State: Political Implications of the McCracken Report', (1978) 31 World Politics 108. The author presciently observed that the Report made a strong political argument, positing that democratic States were to discipline their citizens more effectively in order to conform to the requirements of capitalism.

${ }^{32}$ M. Goldmann, 'The Great Recurrence. Karl Polanyi and the Crises of the European Union', (2017) 23 European Law Journal 272, 277 28.

${ }^{33}$ L. Tsoukalis, The New European Economy Revisited (3rd ed) (Oxford University Press, 1997), 26-

34 S. Deakin, 'Labour Law as Market Regulation. The Economic Foundations of European Social Policy', in P. Davies, A. Lyon-Caen, S. Sciarra, S. Simitis (eds), Principles and Perspectives on EC Labour Law. Liber Amicorum for Lord Wedderburn (Oxford University Press, 1996), 70.

${ }^{35}$ European Commission, Completing the Internal Market. White Paper from the Commission to the European Council, 14 June 1985, COM(85) 310 final.

${ }^{36}$ Ibidem., 4.

37 C.D. Ehlermann, 'The "1992 Project”: Stages, Structures, Results and Prospects', (1990) 11 Michigan Journal of International Law 1097, 1103. The author pointedly observed that "[t]he '1992 Project' has radically changed the European Community. It has given the 'common market' new impetus and has lifted the Community out of the deep crisis in which it was bogged down in the first half of the 1980's". 
aim by introducing qualified majority voting for the adoption of internal market measures under Article 100a EEC. Once again, this reform was presented as only a minor, even technocratic step, couched in terms of a residual procedure to be used only "[b]y way of derogation from Article 100 EEC and save where otherwise provided in this Treaty". However, when considered in retrospect, the impact of this reform was considerable from many points of view. ${ }^{38}$ With specific regard to the issue under discussion, it enhanced the capacity of supranational institutions to affect and constrain national political decisions in fields falling in Member States' exclusive preserve, such as the social one.

Stronger constraints on Member States' social autonomy came from the judiciallyinduced 'infiltration' ${ }^{39}$ of internal market rules into the social sphere. From the 1990s onwards, the Court started to assess the compatibility of key components of national social spaces with the functioning of a competitive internal market. A first strain on national social regimes derived from the attempt to apply competition rules ${ }^{40}$ to public insurance monopolies and to the principle of compulsory membership. Equally troublesome was the application of the norms on the free movement of labour and services to national arrangements, limiting the access to welfare benefits and services. ${ }^{41}$ Other battlegrounds were the application of EU State aid norms to the compensation granted by national authorities to welfare services providers, ${ }^{42}$ as well as by the recourse to the rules on freedom of establishment against the restrictions imposed by Member States on the access of private enterprises to their domestic 'social' markets. ${ }^{43}$ Problems also arose with regard to the interplay between free movement of services and national labour legislation, generating a number of cases touching upon Member States' capacity to impose their own minimum labour standards on workers posted to their territory by enterprises established in other Member States,${ }^{44}$ even in cases where the execution of a public contract was at stake. ${ }^{45}$

The infiltration of internal market law into national social spaces put under pressure

${ }^{38}$ J. Weiler, 'The Transformation of Europe', (1991) 100 The Yale Law Journal 2403, 2461-2463.

${ }^{39}$ G. Lyon-Caen, 'L'infiltration du droit du travail par le droit de la concurrence', (1992) Droit ouvrier 313.

${ }^{40}$ See, among others, Judgment of 17 February 1993, Poucet et Pistre, Cases C-159/91 and C-160/91; Judgment of 16 November 1995, FFSA, Case C-244/94; Judgment of 21 September 1999, Albany, Case C-67/96; Judgment of 22 January 2002, Cisal, Case C-218/00; Judgment of 16 March 2004, AOK Bundesverband, Cases C-264/01, C-306/01, C-354/01, C-355/01.

41 Judgment of 28 April 1998, Kohll, Case C-158/96; 12 July 2001, Smits and Peerbooms, Case C157/99; Judgment of 13 May 2003, Müller-Fauré and Van Riet, Case C-385/99; Judgment of 16 May 2006, Watts, Case C-372/04; Judgment of 9 October 2014, Petru, C-268/13. For a detailed analysis of the case law on patients' mobility see J. Baquero Cruz, 'The Case Law of the European Court of Justice on the Mobility of Patients', in J. van de Gronden, E. Szyszczak, U. Neergaard and M. Krajewski (eds), Health Care and EU Law (TMC Asser Press, 2011), 79-102.

${ }^{42}$ Judgment of 12 February 2008, BUPA, Case T-289/03.

43 Judgment of 11 September 2008, Commission v Germany (Hospital pharmacies), Case C-141/07; Judgment of 10 March 2009, Hartlauer, Case C-169/07.

44 Judgment of 18 December 2007, Laval, C-341/05; Judgment of 18 December 2007, Viking, C438/05; Judgment of 3 April 2008, Rüffert, C-346/06; Judgment of 18 June 2008, Commission $v$. Luxembourg, C-319/06. These cases prompted an intense debate that has been reviewed by C. Barnard, 'The Calm After the Storm: Time to Reflect on EU (Labour) Law Scholarship Following the Decisions in Viking and Laval', in A. Bogg, C. Costello, A.C.L. Davies (eds), Research Handbook on EU Labour Law (Edward Elgar, 2016), 337-362.

45 See F. Costamagna, 'Minimum Wage in EU Law Between Public Procurement and Posted Workers: Anything New Under the Sun After the RegioPost Case?', (2017) 1 European Law Review 101; A. Koukiadaki, 'The Far-Reaching Implications of the Laval Quartet: The Case of the UK Living Wage', (2015) 43 Industrial Law Journal 91; C. Kilpatrick, Internal Market Architecture and the Accommodation of Labour Rights: As Good as It Gets?, EUI Working Paper LAW 2011/04. 
the division of social competences between supranational and national authorities. The Court brought to an end the double-track model and contributed to further limiting Member States' margins of manoeuvre in a field formally their exclusive preserve. The Kohll judgment, concerning an early case on the free circulation of patients, provides an apt example in this regard. Faced with the question of whether Treaty provisions on the free movement of services could apply in the field of social security, the Court reframed it by saying that the problem was not whether the application of these rules could encroach upon national competences, but whether the exercise of the latter could impede the free movement of services' beneficiaries. Indeed, while first acknowledging that "Community law does not detract from the powers of the Member States to organise their social security systems", it added that "Member States must nevertheless comply with Community law when exercising those powers". ${ }^{46}$ Therefore, gone was the stark distinction between the economic and social spheres, since the latter, although still formally within Member States' exclusive competence, was fully embedded in the former.

\subsection{Reconciling the 'economic' and the 'social' within the EU legal order}

The evolution described above was perceived as a force that could encroach upon domestic social solidarity institutions, ${ }^{47}$ driving a de-structuring wedge therein. The strain between the economic and social dimensions is profound. It originates from a clash between two opposing logics: on the one hand, the process of economic integration rests upon a logic of openness; on the other, national social spaces are founded upon a logic of closure. ${ }^{48}$ In particular, as explained by Ferrera, redistributive regimes presuppose "the existence of a clearly demarcated and cohesive community, whose members feel that they belong to same whole and that they are linked by reciprocity ties vis-à-vis common risks and similar needs". ${ }^{49}$ Viewed from an internal market perspective, these spatial demarcations are just restrictions that need to be removed in order to create an integrated and competitive market space.

Member States' reaction to the judicially-induced infiltration materialized in Treaty reforms that, apparently, tried to reinstate and reinforce the old division of labour, so to insulate their social spaces "from the pressures generated from the functioning of the internal market". ${ }^{0}$ This is the case if one looks at the choice to confirm that redistributive functions and the regulation of labour markets still are, by and large, they exclusive preserve. Or, in those cases where steps were taken in the opposite direction, Member States sought to retain the last word in any case. For instance, the Treaty of Lisbon modified Article 48 TFEU, replacing unanimity with qualified majority voting for the adoption of social security measures relating to the free circulation of workers. At the same time, it also introduced an emergency brake enabling each Member State to halt the legislative process when a draft legislative act "would affect important aspects

${ }^{46}$ Kohll, paras. 17-19. See generally L. Azoulai, 'The "Retained Powers" Formula in the Case Law of the European Court of Justice: EU Law as Total Law?’, (2011) 4 European Journal of Legal Studies 192.

${ }^{47}$ C. Joerges, 'A Renaissance of the European Economic Constitution?', in U. Neergaard, R. Nielsen and L.M. Roseberry (eds), Integrating Welfare Functions into EU Law (Djøf Publishing, 2009), 37-51.

${ }^{48}$ For an in-depth analysis of the impact of European integration upon national welfare states see S. Liebfried and P. Pierson, 'Semisovereign Welfare States: Social Policy in a Multitiered Europe', in S. Liebfried and P. Pierson (eds), European Social Policy: Between Fragmentation and Integration (Brooking Institution Press, 1995), 43-77.

${ }^{49}$ M. Ferrera, 'Friends, not Foes: European Integration and National Welfare States', URGE Working Paper, No. 10/2006, 3.

${ }^{50}$ De Witte, above, n. 27 , at 125. 
of its social security systems, including its scope, cost or financial structure, or would affect the financial balance of that system".

Other reforms sought to strengthen the position of national social spaces in the EU constitutional constellation. This is the case, first of all, of the new Article 3 TEU, which gives enhanced visibility to a host of social objectives and put them on a par with economic ones, such as the establishment of the internal market or of the EMU. In the absence of the conferral to the EU of new powers to pursue these objectives, this provision has to be interpreted as meaning that there is no hierarchy between the two set of objectives in the EU legal order and, thus, conflicts are to be solved through a balancing exercise. ${ }^{51}$ This duty is codified by Article 9 TFEU, which establishes, in an admittedly less-than-clear fashion, that EU institutions are bound "to take into account requirements linked to the promotion of a high level of employment, the guarantee of adequate social protection, the fight against social exclusion and a high level of education, training and protection of human health" when acting. A similar balancing function can also be performed by the Charter of Fundamental Rights and, in particular, by the social rights contained therein. Despite their often uncertain wording, these provisions could represent a buffer against the disruptive effects that the application of EU rules can have on the functioning of internal market spaces.

These reforms have the merit of potentially restating the pluralistic character of the European economic constitution, ${ }^{52}$ imposing the duty to solve these conflicts by finding a balance between competing objectives and values that are ranked equally within the EU constitutional order. ${ }^{53}$ The key question is whether the new constitutional constellation nested national social spaces within the supranational order by providing "an environment that allows [their] survival and development" 54 or "absorbed [them] into the province where European constitutional law acts as a disciplinary force". 55

Much depends on the capacity of decision-makers to systematically mobilize the new tools and, even more crucially, on the Court's approach when it comes to balancing the economic and the social. As for the latter, the analysis of the case law does not offer many reasons for hope. The Court often resorted to "hierarchical balancing", ${ }^{56}$ drifting toward the adoption of what has been pointedly described as "total market thinking". 57 The most conspicuous examples in this regard are the Viking and Laval cases. ${ }^{58}$ As openly recognized by AG Trstenjak in Commission v. Germany, "[ $\mathrm{t}]$ he approach adopted in Viking Line and Laval un Partneri" on the relationship between the right to

${ }^{51}$ As explicitly recognized by the Court in a case concerning the compatibility of the Greek legislation on collective redundancies with Article 49 TFEU, the granting of equal constitutional status to the two sets of objectives requires balancing "the rights under the provisions of the Treaty on the free movement of goods, persons, services and capital [...] against the objectives pursued by social policy" (see Judgment of 21 December 2016, AGET Iraklis, Case C-201/15, paras 76-77). This did not deter the Court from finding that the Greek legislation was incompatible with Article 49 TFEU for imposing criteria for the authorization of collective redundancies that are too imprecise and, thus, for failing to comply with the proportionality principle.

${ }^{52}$ C. Kaupa, The Pluralist Character of the European Economic Constitution (Hart Publishing, 2016).

${ }^{53}$ M. Dawson and B. De Witte, 'Welfare Policy and Social Inclusion', in A. Arnull and D. Chalmers (eds), The Oxford Handbook of European Union Law (Oxford University Press, 2015), 965-966.

${ }^{54}$ Ferrera, above, n. 7, at 223-226.

${ }^{55}$ L. Niglia, 'Eclipse of the Constitution. Europe Nouveau Siècle', (2016) 22 European Law Journal $132,138$.

56 Ibid., 154.

57 E. Christodoulidis, 'The European Court of Justice and "Total Market Thinking"”, (2013) 14 German Law Journal 2005, 2011. See also Joerges and Rödl, above, n. 26.

58 See recently S. Giubboni, 'Freedom to Conduct a Business and EU Labour Law', (2018) 14 European Constitutional Law Review 172, 179-180 arguing that "Viking and Laval inaugurate the season of the Court's dominant neoliberal dogmatism". 
take collective action and free circulation of services "sits uncomfortably alongside the principle of equal ranking for fundamental rights and fundamental freedoms [suggesting] the existence of a hierarchical relationship between fundamental freedoms and fundamental rights in which fundamental rights are subordinated to fundamental freedoms". ${ }^{59}$ This is not to deny that there are other cases where the Court avoided market fundamentalism, accepting that economic objectives can yield to social ones and national preferences. ${ }^{60}$ Yet, even in these cases, the Court keeps on starting from the ends of economic freedoms, which is no longer necessary if the above-mentioned Treaty reforms are to be taken seriously.

\section{National social spaces within the EMU}

The push toward completion of the internal market was intimately linked with another important step in the integration process, i.e. the establishment of the Economic and Monetary Union (EMU) ${ }^{61}$ Since its inception, it was clear that the creation of the EMU would involve "a huge transfer of power from the national to the EU level" 62 negatively affecting social policies, which could end up being "the very likely victim of EMU". ${ }^{63}$ As duly observed in the Delors Report of 1989, the creation of the EMU would increase economic interdependence and, thus, "reduce the room for independent policy manoeuvre and amplify the cross-border effects of developments originating in each member country". ${ }^{64}$ Therefore, in the absence of a truly common economic policy, there was the need to place national decisions "within an agreed macroeconomic framework and be subjected to binding procedures and rules". ${ }^{65}$ Yet, the Delors Report warned that these efforts could not be enough to ward off the risk that the creation of a single currency area, founded on full capital mobility, could aggravate the imbalances existing between Member States, negatively affecting "peripheral regions". ${ }^{66}$ Consequently, the Report emphasised the need for the adoption of "countervailing policies" at supranational level in order to compensate Member States' loss, as a result

${ }^{59}$ Opinion of AG Trstenjak of 14 April 2010, Commission v. Germany, C-271/08, paras 183-184. For a critical view on the 'equal ranking' doctrine see Goldmann, above, n. 32, at 280.

${ }^{60} \mathrm{See}$, for instance, judgment of 11 December 2014, Spezzino, C-113/13. For a critical analysis of the decision of the Court, see R. Caranta, 'After Spezzino (Case-C-113/13): A Major Loophole Allowing Direct Awards in the Social Sector', (2016) European Procurement \& Public Private Partnership Law Review 14.

${ }^{61}$ The necessity of EMU for completion of the Internal Market is often explained by referring to the so-called "impossible trinity" principle, according to which "full capital mobility and exchange rates fixity remove the ability to conduct an independent monetary policy. Under the assumption that the exchange rate stability is seen as a condition for the smooth working of the Common Market, it follows that all countries except one have lost de facto monetary policy independence. The monetary union recognizes this fact and makes sure that no country will mistakenly challenge the impossible trinity principle” (C. Wyplosz, 'The European Monetary Union. The Dark Sides of a Major Success', (2006) 21 Economic Policy 207, 212).

${ }^{62}$ P. Teague, 'Monetary Union and Social Europe', (1998) 8 Journal of European Social Policy 117, 118-119. 75.

${ }^{63}$ D. Bouget, 'Social Policy in the EMU: Between a Dream and a Nightmare', (1998) 1 Transfer 67,

${ }^{64}$ Committee for the Study of Economic and Monetary Union (Delors Report), Report on Economic and Monetary Union in the Community, 1989, 10.

${ }^{65}$ Ibid., 14.

${ }^{66}$ Ibid., 18. Quite remarkably, the Padoa-Schioppa Report of 1987 had already warned against the "serious risk of aggravated regional imbalances" through market integration, calling for the strengthening of allocative and, even more importantly, redistributive functions at supranational level. See T. PadoaSchioppa, Efficiency, Stability and Equity. A Strategy for the Evolution of the Economic Strategy of the European Community. A Report of a Study Group Appointed by the Commission of the European Communities (European Commission, 1987), 4. 
of EMU, of the monetary levers with which to address financial imbalances. As a consequence, Member States should put the Community in the position of promoting "an optimum allocation of resources and [...] spread welfare gains throughout the Community", enlarging the size of regional funds to use them to equalize production conditions through investment programmes "in such areas as physical infrastructures, communications, transportation and education". ${ }^{67}$

With the benefit of hindsight, one cannot but regret that the establishment of the EMU focused more on the first aspect, the creation of a macroeconomic framework of binding rules and procedures, than on the second, the need to confront structural imbalances. ${ }^{68}$ The framework revolved around a set of criteria, concerning public deficit and debt, enshrined in the Stability and Growth Pact (SGP). ${ }^{69}$ Budgetary constraints were binding on Member States, which could be ultimately sanctioned for failing to respect them. ${ }^{70}$ Budgetary discipline was complemented by the establishment of mechanisms for the coordination of Member States' economic and social policies. This coordinative form of governance, traditionally known as Open Method of Coordination (OMC), had a soft character, being a voluntary process for political cooperation based on agreeing common objectives and measuring progress towards these goals using common indicators. ${ }^{71}$ Their soft nature allowed supranational institutions - and, in particular, the European Commission - to exert their influence, which varied considerably from process to process, in fields falling outside EU competencies and, thus, beyond the limits set by the principle of conferral. ${ }^{72}$

Both components of the framework were set to have a potentially profound impact on national social spaces. On the one hand, budgetary constraints aimed at limiting Member States' capacity to play "Keynes at home", forcing them, in particular, to cut down on one of the heaviest items in their budgets, i.e. social expenditure. ${ }^{73}$ On the other, most of the policy coordination processes touched upon, directly or indirectly, social issues. Indeed, after being first used with regard to economic policies, ${ }^{74}$ the OMC

${ }^{67}$ Ibid., 18-19. What the Delors Report seems oblivious to is the massive shift of power toward the supranational level that this would have caused. On this point see P. Baffi, 'Il sistema monetario europeo e la partecipazione dell'Italia, testo dell'audizione del governatore della Banca d'Italia alla Commissione Finanze e Tesoro del Senato del 26 ottobre', (1978) 2 Thema 7.

${ }^{68}$ F. Amtenbrink, 'The Methamorphosis of European Economic and Monetary Union', in Arnull and Chalmers, above, n. 53, at 722 .

${ }^{69}$ Resolution of the European Council on the Stability and Growth Pact (Amsterdam, 17 June 1997), OJ C 236 of 02.08.1997; Council Regulation (EC) No 1466/97 of 7 July 1997 on the strengthening of the surveillance of budgetary positions and the surveillance and coordination of economic policies, OJ L 219 of 02.08.1997.

70 Council Regulation (EC) No 1467/97 of 7 July 1997 on speeding up and clarifying the implementation of the excessive deficit procedure, OJ L 209 of 02.08.1997.

${ }^{71}$ See K.A. Armstrong, The Open Method of Coordination - Obstinate or Obsolete?, University of Cambridge Faculty of Law Legal Studies Research Paper Series, Paper No. 45/2016.

${ }^{72}$ For an early critical take on this aspect, see L. Cram, 'Calling the Tune without Paying the Piper? Social Policy Regulation and the Role of the Commission in European Community Social Policy', (1993) 21 Policy \& Politics 135.

73 See A. Vedun, 'An Asymmetrical Economic and Monetary Union in the EU: Perceptions of monetary Authorities and Social Partners', (1996) 20 Journal of European Integration 59. Back in the mid-'90s, the Author conducted interviews with politicians and experts on the upcoming monetary union, revealing that many of them backed the creation of the EMU just because it "would offer legitimacy for restructuring the expensive welfare states".

${ }^{74}$ Finding a legal basis in the Treaty in what is now Article 121 TFEU. The provision establishes that "Member States shall regard their economic policies as a matter of common concern and shall coordinate them within the Council". 
then spread to the field of employment policy $^{75}$ and, later, to social inclusion, pensions and healthcare. ${ }^{76}$

Despite being seemingly very intrusive into national decisional autonomy, in reality the mechanisms described above were designed to preserve some space for national politics. $^{77}$

On the one hand, SGP fell victim to its "design faults and cardinal sins" purposely introduced by Member States to avoid that the Union could effectively "interfere with one of their core policy areas, that is, to decide upon government expenditure and taxation or, in short, their budgetary freedom". ${ }^{78}$ A good example in this regard is the choice to entrust the Council with the authority to adopt a number of key decisions in the process, such as, for instance, the one approving a sanction against a State failing to meet the budget target or breaching the deficit criterion. This gave Member States the ultimate say on decisions that one day could come back to haunt them. Therefore, it comes as little surprise that Member States have mostly used these prerogatives to safeguard their present and future interests, rather than to ensure strict compliance with the rules. In 2003, for instance, the ECOFIN brushed aside Commission recommendations requiring France and Germany to bring their deficits under the 3 percent threshold by the following year. ${ }^{79}$ This choice, motivated by the need to avoid pushing the whole Eurozone into recession, deepened the rift between large Member States and small ones. ${ }^{80}$ It eventually led to a reform of the SGP in 2005 that relaxed the requirements, adding a little more flexibility. ${ }^{81}$

On the other hand, coordination mechanisms failed to force Member States to reform their social spaces to make them converge toward a set of goals, such as increasing labour flexibility, modernizing social protection systems or creating an "active and dynamic welfare state". ${ }^{82}$ This was, at least, the perception of the European

75 The European Employment Strategy was launched in November 1997 at the Luxembourg European Council, after the Amsterdam Treaty had laid the basis for that step. See generally D. Ashiagbor, The European Employment Strategy (Oxford University Press, 2005).

${ }_{76}$ In 2006, the social inclusion, pensions and healthcare processes were streamlined into a single Social OMC (European Commission, A New Framework for the Open Coordination of Social Protection and Inclusion Policies, COM(2005)706, 22.12.2005). The Lisbon Strategy (European Council, Lisbon Presidency Conclusions, 23-24 March 2000) represented a breakthrough for this development, since it gave stronger visibility to social policy within the integration process and it formally introduced the OMC as a new governance tool. See generally K.A. Armstrong, Governing Social Inclusion: Europeanization through Policy Coordination (Oxford University Press, 2010).

77 J. Snell, 'The Trilemma of European Economic and Monetary Integration, and Its Consequences', (2016) 22 European Law Journal 157, 160-164.

${ }^{78}$ R. Palmstorfer, 'The Reverse Majority Voting Under the 'Six Pack': A Bad Turn for the Union?', (2014) 20 European Law Journal 186, 188-191.

79 Decision 2003/89/EC on the existence of an excessive deficit in Germany-Application of Article 104(6) of the Treaty establishing the European Community, OJ L34 of 11.02.2003; Decision 2003/487/EC on the existence of an excessive deficit in France-Application of Article 104(6) of the Treaty establishing the European Community, OJ L165 of 03.07.2003. On 25 November 2003, the Council voted on the recommendations, failing to reach the required majority. The Commission brought an action of annulment against the non-decision of the Council, but the Court dismissed it (see Judgment of 13 July 2004, Commission v. Council, C-27/04, paras. 25-36).

${ }^{80}$ Editorial Comments, 'Whither the Stability and Growth Pact?', (2004) 41 Common Market Law Review 1193, 1194.

${ }^{81}$ Council Regulation (EC) No 1055/2005 of 27 June 2005 amending Regulation (EC) No 1466/97 on the strengthening of the surveillance of budgetary positions and the surveillance and coordination of economic policies, OJ L174 of 07.07.2005 and Council Regulation (EC) No 1056/2005 of 27 June 2005 amending Regulation (EC) No 1467/97 on speeding up and clarifying the implementation of the excessive deficit procedure, OJ L174 of 07.07.2005.

${ }^{82}$ Lisbon Presidency Conclusions, above, n. 76, at 24. 
Commission, which, for instance, in 2008 expressed its frustration with the inadequate results achieved in the field of social policy coordination and, in particular, in the domain of pension reforms. ${ }^{83}$ An exhaustive assessment of the merits and demerits of the OMC falls well beyond the scope of this article. However, such a negative assessment is worth careful consideration, since it reveals how, especially starting from the launch of the Lisbon Strategy in 2005, the Commission changed its view on the OMC. Rather than considering it just as a process of reflexive harmonization based on mutual learning and policy exchange, aimed at opening up space for autonomy and differentiation, ${ }^{84}$ it came to regard it as a tool that should be able to force national social spaces into a more market-oriented and EMU-friendly mould. Or, to use the words of Chalmers and Lodge, to push further the process of "colonization of the welfare state by the economic policy making process", 85 circumventing the limits posed by the principle of conferral.

\section{The reform of the European economic governance and the impact on national social spaces: the case of the European Semester}

The leniency of budgetary constraints and the ineffectiveness of economic policy coordination mechanisms have often been regarded as indirect causes of the crisis, allowing some States, especially Southern ones, to overspend on social welfare and to procrastinate the reform of their social protection systems and labour market. The Commission, together with some Member States, touted this narrative, which, disregarding EMU's structural defects, laid the groundwork for and inspired subsequent reforms.

First, in 2011 the EU adopted a package of six legal acts, commonly referred to as the Six-Pack, reforming SGP's preventive and corrective arms. Procedurally, one of the main objectives of this reform was to give more power to supranational institutions and, in particular, to the Commission, by taking it away from the Council. ${ }^{86}$ The introduction of minority voting in various stages of the procedure ${ }^{87}$ goes exactly in this direction, ${ }^{88}$ making it more difficult for Member States to gather enough support to block the adoption of a Commission's recommendation. Substantively, the reform aimed at expanding the scope of supranational control beyond debt and deficit, so as to take into account macroeconomic imbalances and competitiveness developments. In particular, Regulation (EU) No. 1176/2011 and Regulation (EU) No. 1174/2011 introduced a new procedure, largely modelled after the SGP, that should allow for an early detection and correction of imbalances heightening the financial vulnerability of Member States and of the euro area as a whole.

Second, and this will be the main focus of the next sub-sections, the EU has sought to strengthen the coordination of economic policies with the creation of the European

\footnotetext{
${ }^{83}$ European Commission, A Renewed Commitment to Social Europe: Reinforcing the Open Method of Coordination for Social Protection and Social Inclusion, COM(2008)418 final, 22 July 2008, 2.

${ }^{84}$ Giubboni, above, n. 25, at 119.

${ }^{85}$ D. Chalmers and M. Lodge, The Open Method of Co-ordination and the European Welfare State, ESRC Centre for Analysis of Risk and Regulation, Discussion Paper No. 11/2003, 14

${ }^{86}$ For a critical account of the reforms introduced by the Six-Pack see D. Adamski, 'National Power Games and Structural Failures in the European Economic Governance', (2012) 49 Common Market Law Review 1336.

${ }^{87}$ Article 7 of the Treaty on Stability, Coordination and Governance in the Economic and Monetary Union extended the use of this voting procedure, committing the Contracting Parties whose currency is the euro "to support the proposals or recommendations submitted by the European Commission where it considers that a Member State of the European Union whose currency is the euro is in breach of the deficit criterion in the framework of an excessive deficit procedure"

${ }^{88}$ Palmstorfer, above, n. 78, at 91-94.
} 
Semester. Despite showing many elements of continuity with past OMC processes, the new framework seeks to address some of their perceived organizational and ideational shortcomings.

\subsection{Social and Labour Soft Policy Coordination under the Shadow of Hard Law Processes within the European Semester \\ Procedurally, the Semester brings under the same umbrella different strains of EU} policy coordination and surveillance that touch upon both economic and social policies. The creation of a hybrid meta-coordination framework, yoking together hard and soft law processes, allegedly aimed at increasing consistency among instruments that have different legal bases and rely upon distinct enforcement mechanisms. In reality, the main objective was to put hard law mechanisms at the service of soft coordinative governance tools, in order to strengthen the capacity of supranational institutions of making national authorities comply with guidelines and recommendations touching upon subject matters, such as pensions and wage-setting mechanisms, that fall within national competences. ${ }^{89}$ From a normative standpoint, the choice to put coercion at the service of flexible arrangements is problematic.

The Semester rests upon three main pillars, namely the Europe 2020 Integrated Guidelines, the Stability and Growth Pact and the Macroeconomic Imbalances Procedure (MIP). It starts in November, when the Commission adopts the Annual Growth Survey (AGS), whose content, after being endorsed by the European Council, should feed into Member States' National Reform Programmes (NRPs) and Stability or Convergence Programmes (SCPs). In May, the Commission evaluates national reform and fiscal plans and it issues Country-Specific Recommendations (CSRs) that set out the actions to be taken by the concerned State. In July, CSRs are finally approved by the ECOFIN Council. The approval of 'the Two-Pack' ${ }^{90}$ and, in particular, the adoption of Regulation (EU) No. 473/2013 added a further step to the Semester, at least with regard to Euro States. Indeed, since 2013 the latter have been required to submit to the Commission by 15 October a draft budgetary plan for the following year. This allows the Commission to look into the measures proposed by national Governments at a moment in which these measures, and their modes of implementation, are discussed by national parliaments. The Commission has the power to step into the debate and, should it identify serious non-compliance with SGP obligations, even request the State concerned to submit a revised plan within three weeks. ${ }^{91}$

The combination of hard and soft mechanisms enhances supranational institutions' capacity to exercise policy formulation, supervision and guidance on issues concerning the organization and functioning of national social spaces. ${ }^{92}$ As seen above, this does

${ }^{89}$ M. Dawson, 'New Governance and the Displacement of Social Europe: The Case of the European Semester', (2018) 14 European Constitutional Law Review 191, 197-199. See, more in general, F. Amtenbrink and R. Repasi, 'Compliance and Enforcement in Economic Policy Coordination in EMU', in A. Jakab and D. Kochenov (eds), The Enforcement of EU Law and Values. Ensuring Member States' Compliance (Oxford University Press, 2017), 145-181.

${ }^{90}$ Composed of two different legislative measures, both addressing Euro States only: a Regulation (EU) No. 472/2013 of the European Parliament and the Council of 21 May 2013 on the strengthening of economic and budgetary surveillance of Member States in the euro area experiencing or threatened with serious difficulties with respect to their financial stability [2013] OJ L140/1 and Regulation (EU) No. 473/2013 of the European Parliament and of the Council of 21 May 2013 on common provisions for monitoring and assessing draft budgetary plans and ensuring the correction of excessive deficit of the Member States in the euro area [2013] OJ L140/11.

${ }^{91}$ Art 6 of Regulation (EU) No. 473/2013.

92 See generally S. Bekker, European socioeconomic governance in action: Coordinating social policies in the third European Semester, OSE Paper Series No. 19/2015; F. Costamagna, 'The Impact of 
not represent an absolute novelty in the EU legal order, since EU institutions were able to exercise these functions in the context of already-existing soft policy coordination processes. However, the new framework is not a mere sum of past soft law processes: coordination activities are now carried out under the shadow of hard law measures, or even financial sanctions for Euro States, that can be adopted against those member States that fail to comply with the recommendations. Chalmers described it as a process of co-government that "goes to the structure and rationale of a State's fiscal and welfare systems". ${ }^{93}$ Admittedly, this may seem an overstatement if measured against the implementation of recommendations at national level, which, as lamented by the Commission in the AGS 2017, is still "disappointing". ${ }^{4}$ However, the notion well captures the potential of a process that combines the breadth and specificity of soft coordination mechanisms with the stealth of surveillance procedures having a hard law nature. This emerges very clearly if one considers CSRs dealing with social and labour policy issues.

These acts are not just "broad guidelines" as provided for by Article 121 TFEU, being very specific in identifying the measures to be adopted and the results to be achieved. Rather than broad guidelines, many of the recommendations look like narrow paths not allowing for any deviation from what EU institutions - and the Commission, in particular - consider as the 'right way' toward salvation. For instance, in 2015 Ireland was recommended to "[t]ake measures to increase the cost-effectiveness of the healthcare system, including by reducing spending on patented medicines and gradually implementing adequate prescription practices. Roll out activity-based funding throughout the public hospital system". ${ }^{95}$ Likewise, in 2016 Austria was asked to "[e]nsure the sustainability of the healthcare system, and of the pension system by linking the statutory pension age to life expectancy". ${ }^{96}$

These recommendations obliterate national authorities' autonomy, leaving noncompliance as the only possible way out. Yet, this option is not readily available to all Member States. Despite nominally retaining a non-binding character, these recommendations engender a level of compliance that is higher than the one that may be inferred from Article 288 TFEU. Indeed, the Commission can use hard-law processes, such as the SGP, to put pressure on national authorities so to make them adopt the recommended reforms in the social and labour fields. Due to its power-based nature, the effectiveness of the mechanism depends on the vulnerability of the State to this threat. Those States at risk of being put under an excessive deficit procedure have few other options apart from complying with the supranational recommendations.

The case of France and, more specifically, the adoption of the so-called Loi Khomri (or Loi Travail) offers a good example in this regard. ${ }^{97}$ After the eruption of the crisis, the French budgetary position was problematic, and in 2009 the Council formally

Stronger Economic Policy Coordination on the European Social Dimension: Issues of Legitimacy', in M. Adams, F. Fabbrini and P. Larouche (eds), The Constitutionalization of European Budget Constraints (Hart Publishing, 2015), 359-377

93 D. Chalmers, 'The European Redistributive State and a European Law of Struggle', (2012) 18 European Law Journal 667, 679-681. Further on this point, D. Chalmers, 'Crisis Reconfiguration of the European State', in D. Chalmers, M. Jachtenfuchs and C. Joerges (eds.) The End of the Eurocrats Dream (Cambridge University Press, 2016), 266-298.

${ }^{94}$ At 3

95 Council Recommendation of 14 July 2015 on the National Reform Programme 2015 of Ireland and delivering a Council opinion on the Stability Programme of Ireland, 2015, OJ C 272 of 18.08.2015, 45.

${ }^{96}$ Council Recommendation of 12 July 2016 on the National Reform Programme 2014 of Austria and delivering a Council opinion on the Stability Programme of Austria, 2016, OJ C 299 of 18.08.2016, 60.

${ }^{97}$ R. Erne, 'A Supranational Regime that Nationalizes Social Conflict: Explaining European Trade Unions’ Difficulties in Politicizing European Economic Governance', (2015) 56 Labor History 345, 348. 
opened an excessive deficit procedure against France. ${ }^{98}$ Little happened until 2013, when the Commission and the Council started to put greater emphasis on the link between the "correction of the fiscal imbalances" and "a credible implementation of ambitious structural reforms to increase the adjustment capacity and boost growth and employment". ${ }^{99}$ In particular, France was recommended to reduce the cost of labour and to "ensure that developments in the minimum wage are supportive of competitiveness and job creation". ${ }^{100}$ The same happened, with only minor terminological variations, in $2014^{101}$ and 2015. ${ }^{102}$ All these recommendations were adopted on the basis of Article 6 Regulation (EU) No. 1176/2011. In February 2015, the French Government bowed to the pressure, passing a law that aimed at rendering the labour market more businessfriendly. The law was adopted by an executive order, ${ }^{103}$ so as to avoid that the Assemblée Nationale could reject it and thus send "the wrong signal to the European Commission, a week before deciding whether to fine France for missing its deficit targets". ${ }^{104}$ The decision paid off as the Commission refrained from penalizing France, despite its failure to bring the deficit under the 3 percent threshold. ${ }^{105}$

\subsection{The subordination of social objectives to economic ones within the Semester}

The choice of bringing social and labour policy coordination under the shadow of SGP and MIP has a bearing also on the ideational component of the Semester and, in particular, on the relationship between economic and social objectives therein. This framework has been created to fill a gap within the EMU. Therefore, it comes as little surprise that it tends to focus on a narrow set of policy objectives, such as budgetary discipline and competitiveness, which are seen as contributing to the strengthening of the EMU, prioritising them over potentially conflicting goals, such as social ones. ${ }^{106}$ More in detail, national social spaces have been mostly considered either as a cost to be reduced in order to balance the budget or as a factor that, if duly 'modernized', could contribute to boosting the competitiveness of the State. Barring few notable exceptions,

98 Council Decision No. 2009/414/EC of 27 April 2009 on the existence of an excessive deficit in France, OJ L 135 of 30.05.2009, 19-20.

${ }^{99}$ Council Recommendation of 9 July 2013 on the National Reform Programme 2013 of France and delivering a Council opinion on the Stability Programme of France, 2012-2017, OJ C 217 of 30.07.2013, 31 .

${ }^{100}$ Ibidem.

${ }^{101}$ Council Recommendation of 8 July 2014 on the National Reform Programme 2014 of France and delivering a Council opinion on the Stability Programme of France, 2014, OJ C 247 of 29.07.2014, 4748.

102 Council Recommendation of 14 July 2015 on the 2015 National Reform Programme of France and delivering a Council opinion on the 2015 Stability Programme of France, OJ C 272 of 18.08.2015, 55.

${ }^{103}$ The Loi Travail has been published in the Journal officiel only on the 6th August 2016, after that several versions have been rejected either by the Assemblée Nationale or by the Senat. Many of the most controversial aspects of the original version of the Loi have been amended or scrapped altogether, so that, just a few days after his election, President Macron announced a new reform of the law. This push finds strong support at supranational level, as demonstrated by the recommendation issued in 2016 by the Council, which invited the French Government to "ensure that the labour cost reductions are sustained and that minimum wage developments are consistent with job creation and competitiveness" (Council Recommendation of 12 July 2016 on the 2016 National Reform Programme of Finland and delivering a Council opinion on the 2016 Stability Programme of Finland, OJ C 299 of 18.08.2016, 82).

104 A-S. Chassany, 'French Government Overrides Parliament to Ram though Reforms', Financial Times, online edition, 17 February 2015 https://www.ft.com/content/3e2f4314-b67b-11e4-a5f200144 feab7de

${ }^{105}$ European Commission, Recommendation for a Council Recommendation with a view to bringing an end to the excessive government deficit in France, 27 February 2015, COM(2015) 115 def.

106 S. Giubboni, 'The Rise and Fall of EU Labour Law', (2018) 24 European Law Journal 7, 9-10; Dawson, above, n. 89, at 196. 
scant consideration has been paid to their capacity to pursue their typical objectives, such as advancing dignity, cohesion and social justice. ${ }^{107}$ The Semester has thus contributed to accentuating the process of colonization of national social spaces by economic policy's logic and priorities. ${ }^{108}$

Budgetary discipline has long represented the main objective of the coordination system. This is hardly surprising for a framework whose stated aim is to ensure the smooth functioning of the EMU. Indeed, budgetary discipline has been long recognized as a key component of the economic and monetary regime established by the Maastricht Treaty, ${ }^{109}$ and it has been enshrined in Protocol No. 12 attached to the Treaties. Some of the measures adopted in the aftermath of the crisis have further enhanced its status, as is the case of Article 3 of the Treaty on Stability, Coordination and Governance in the Economic and Monetary Union ${ }^{110}$ that required the Contracting Parties to give effect to the balanced budget rule through binding provisions, "preferably constitutional". ${ }^{111}$ The AGS 2011, the first ever adopted, made it clear that its "first priority" was "to set budgetary policies on a sound footing through rigorous fiscal consolidation". ${ }^{12}$ A similar reference, albeit couched in more circuitous terms, can be found in the AGS 2016, which stressed the "need to continue to support growth- and equity-friendly fiscal consolidation in many countries", by making sure that "social protection systems [are] modernised to efficiently respond to risks throughout the lifecycle while remaining fiscally sustainable in view of the upcoming demographic challenges". ${ }^{113}$ Interestingly enough, the prioritization of fiscal discipline over any other objective is conceived, as explained in the AGS 2012, as "a basis [...] to securing the future of the European social model". 114

CSRs, especially those of the early cycles of the Semester, are fully in line with this approach. They treat the reduction of social expenditure as the main route towards fiscal probity. Pensions have traditionally attracted much attention in this context, due to their importance for national budgets. Therefore, over the years several States have been recommended to reform their pension regimes with the primary aim of ensuring their long-term sustainability: this has been the case of Austria, Belgium, Bulgaria, Cyprus, Czech Republic, Finland, Lithuania, Luxembourg, Malta, the Netherlands, Poland, Slovakia, Slovenia and Spain, among others. The content of these recommendations is strikingly similar, pushing the State concerned to "contain future public expenditure growth relating to ageing, in particular from pensions and long-term care, by stepping up efforts to reduce the gap between the effective and statutory retirement age, bringing forward the reduction of early-exit possibilities, promoting active ageing, aligning the

107 From this perspective, the Semester has represented a step back if compared with previous EU programmatic documents. Indeed, one of the merits of the Lisbon Agenda and, to a more limited extent, of the Europe 2020 Strategy was the enhancement of the visibility and the political salience of a number of core social objectives, such as fighting poverty and social exclusion. See M. Jessoula, 'Europe 2020 and the Fight Against Poverty - Beyond Competence Clash, Towards 'Hybrid" Governance Solutions?', (2015) 49 Social Policy and Administration 490.

${ }^{108}$ Dawson and De Witte, above, n. 53, at 984.

109 J. Herdegen, 'Price Stability and Budgetary Restraints in the Economic and Monetary Union: The Law as Guardian of Economic Wisdom', (1998) 35 Common Market Law Review 9, 10.

${ }^{110}$ Signed on 2 March 2012 and entered into force on 1 January 2013.

111 L. Azoulai et al., Another Legal Monster? An EUI Debate on the Fiscal Compact Treaty, EUI Working Paper 2012/9, 4-5.

112 European Commission, Annual Growth Survey. Advancing the EU's Comprehensive Response to the Crisis, 12 January 2011, COM(2011) 11 final, 9.

113 European Commission, Annual Growth Survey 2016. Strengthening the Recovery and Fostering Convergence, 26 November 2015, COM(2015) 690 final, 5.

${ }^{114}$ European Commission, Annual Growth Survey 2012, 23 November 2011, COM(2011) 815 final, 4. 
retirement age to changes in life expectancy". ${ }^{115}$ Health care, another very costly component of national social spaces, has also been subject to close attention in this context. For instance, in 2014, Luxembourg was recommended, "in view of ensuring fiscal sustainability, [to] curb age-related expenditure by making long-term care more cost-effective", ${ }^{116}$ while Ireland was asked to "advance the reform of the healthcare sector initiated under the Future Health strategic framework to increase costeffectiveness. Pursue additional measures to reduce pharmaceutical spending, including through more frequent price realignment exercise for patented medicines, increased generic penetration and improved prescribing practices". ${ }^{117}$ Similarly, in 2017 the Council recommended Portugal to "strengthen expenditure control, cost effectiveness and adequate budgeting, in particular in the health sector with a focus on the reduction of arrears in hospitals and ensure the sustainability of the pension system". ${ }^{118}$

As the fiscal position of Member States gradually improved, another objective rose to prominence in the context of the European Semester, even outweighing budgetary discipline. The promotion of growth by enhancing Member States' competitiveness and capacity to attract private investments progressively become the main aim of the coordination framework, especially after the Commission itself recognized that "[f]iscal consolidation and financial repair are not sufficient in themselves". ${ }^{119}$

As observed with regard to budgetary discipline, also this set of recommendations tends to make the functioning of social protection systems and the regulation of the labour market subject to the achievement of overarching economic objectives, such as economic growth, competitiveness and job creation. As made clear in the AGS 2017, social policy is primarily, if not exclusively, a "productive factor", ${ }^{120}$ which must be "redesigned" in order to enhance efficiency, cost containment and private participation. Once again, little attention is given to principles, such as solidarity, equity, inclusion and cohesion, which are the bedrock of the traditional paradigm of the welfare state.

${ }^{115}$ Council Recommendation of 8 July 2014 on the National Reform Programme 2014 of Belgium and delivering a Council opinion on the Stability Programme of Belgium 2014, OJ C 247 of 29.07.2014, 5. The recommendation was reiterated in the following year, when Belgium launched the reform of its pension system. The CSR 2015 asked Belgian authorities to "complement the pension reform by linking the statutory retirement age to life expectancy" (Council Recommendation of 14 July 2015 on the National Reform Programme 2015 of Belgium and delivering a Council opinion on the Stability Programme of Belgium 2015, OJ C272 of 18.08.2015, 27).

${ }^{116}$ Council Recommendation of 8 July 2014 on the National Reform Programme 2014 of Luxembourg and delivering a Council opinion on the Stability Programme of Luxembourg, 2014, OJ C 247 of 29.07.2014, 76 .

117 Council Recommendation of 8 July 2014 on the National Reform Programme 2014 of Ireland and delivering a Council opinion on the Stability Programme of Ireland, 2014, OJ C 247 of 29.07.2014, 33. Ireland received a similar recommendation also in 2015 , when it was asked to "[t]ake measures to increase the cost-effectiveness of the healthcare system, including by reducing spending on patented medicines and gradually implementing adequate prescription practices" (Council Recommendation of 14 July 2015 on the 2015 National Reform Programme of Ireland and delivering a Council opinion the 2015 Stability Programme of Ireland, OJ C 272 of 18.08.2015, 45).

118 Council Recommendation of 11 July 2017 on the 2017 National Reform Programme of Portugal and delivering a Council opinion on the 2017 Stability Programme of Portugal, OJ C 261 of 09.08.2017, 97

119 AGS 2012, above, n. 114, at 7.

${ }^{120}$ European Commission, Annual Growth Survey 2017, 16 November 2016, COM(2016) 725 final, 12. See M. Ferrera, Liberal Neo-Welfarism: New Perspectives for the European Social Model, OSE Paper Series No. 14/2013. Dawson, above, n. 89, at 206-207 observing that this approach has now found its way into how social actors see social policy within the Semester. The Social Protection Committee began its assessment of the 2017 cycle by stating that "social policy should be seen as an investment and a productive factor" (Employment Committee and Social Protection Committee, Assessment of the 2017 Country-Specific Recommendations and the Implementation of the 2016 CSRs, 7 June 2017, 9653/17, 2). 
The reform of the labour market and, in particular, of wage-setting mechanisms aimed at removing those elements perceived as 'rigidities' are ever-present ingredients of these recipes. For instance, the AGS 2012, after a reference to the need to implement "balanced flexisecurity policies", urged Member States to move forward in "revising wage setting mechanisms [...] to better reflect productivity developments". ${ }^{121}$ The AGS 2013 went even further by praising the "ambitious reforms" that had been implemented across Europe in order to "facilitate flexible working arrangements within firms, reduce severance pay for standard contracts and simplify individual or collective dismissal procedures". ${ }^{22}$ The AGS 2017 exhorted Member States to "make sure that their wagesetting systems are effective in delivering both job creation and real income increases, and for that adjust better to changes in productivity over time". ${ }^{123}$

CSRs follow the very same track, as well demonstrated by the case of France described above or by Finland, which, in 2016, was recommended, "[to] ensure that the wage setting system enhances local wage bargaining and removes rigidities, contributing to competitiveness and a more export industry-led approach". ${ }^{124}$

5.3 The socialization of the European Semester and the EMU Social Dimension: Any real change of paradigm?

Over the years, EU institutions have acknowledged the need to reconfigure the relationship between economic and social objectives within the new European economic governance. The same approach underpins other initiatives aimed at reinforcing the social dimension of the EMU. In 2013, the Commission adopted a Communication on "Strengthening the Social Dimension of the Economic and Monetary Union". ${ }^{25}$ The document, which represents the follow-up to the blueprint for a deep and genuine Economic and Monetary Union, ${ }^{126}$ duly recognized that rebalancing the social and economic dimensions is not just desirable from an economic and political perspective; it is also a legal duty under Article 9 TFEU. However, what follows does not fulfil the expectations generated by these potentially far-reaching premises. Indeed, according to this document, "the "social dimension of the EMU relates to the ability of economic governance mechanisms and policy instruments to identify, take into account and address problematic developments and challenges related to employment and social policies in the EMU". ${ }^{127}$ The definition makes no reference to the possibility that safeguarding the values and interests that underpin the social dimension may limit, or even trump, the pursuit of EMU objectives, as was the case when the very same notion was introduced in the context of the internal market. Deprived of its rebalancing function, this dimension is still considered just as a constitutive element of EMU, to be safeguarded as long as it can contribute to the achievement of its core objectives by addressing issues - such as unemployment and social problems - that "hold back competitiveness and the growth potential of the economies concerned". ${ }^{128}$ This

${ }^{121}$ AGS 2012, above, n. 114, at 10.

${ }^{122}$ European Commission, Annual Growth Survey 2013, 28 November 2012, COM(2012) 750 final, 10.

${ }^{123}$ AGS 2017, above, n. 120, at 11.

${ }^{124}$ Council Recommendation of 12 July 2016 on the 2016 National Reform Programme of Finland and delivering a Council opinion on the 2016 Stability Programme of Finland, OJ C 299 of 18.08.2016.

${ }^{125}$ European Commission, Strengthening the Social Dimension of the Economic and Monetary Union, Brussels, 02.10.2013, COM(2013) 690 def.

${ }^{126}$ European Commission, A Blueprint for a Deep and Genuine Economic and Monetary Union. Launching a Debate, Brussels, 30 November 2012, COM(2012) 777 final/2.

127 Ibidem, 3.

${ }^{128}$ Ibidem. 
document, as well as others adopted later, consolidates the idea that, from a supranational perspective, national social spaces' functions and aims are merely a component of the EMU apparatus. As explained in a strategic note adopted by the Commission in 2015, "the performance of the euro area depends in no small measure on the effectiveness of its members' social systems. Indeed, social imbalances pose a political and economic threat to the sustainability of the euro area, similar in magnitude - even if different in character - to economic and financial risks". ${ }^{129}$

Operationally, the strengthening of the EMU social dimension was pursued mainly through the 'socialization' of the European Semester. ${ }^{130}$ This process touched upon both its organizational and its substantive components.

As for the first aspect, since 2013 there has been an attempt to make the drafting of the CSRs more collaborative, involving Commission Directorates General other than just ECFIN. This should have contributed to opening up the whole process to social issues and concerns. Moreover, the Commission tried to enhance the participation of national and EU social partners in various supranational phases of the coordination process, establishing new venues for involvement and providing better access to decision-making fora. These changes, albeit certainly welcome and potentially interesting, have had a limited impact on the way in which the Semester works, at least so far. For instance, looking at the involvement of social partners, a recently published paper warns against the risk that all these reforms may well end up by increasing social partners' opportunities to be listened to, while leaving substantially unchanged their capacity to be heard. ${ }^{131}$

Turning to the substantive dimension, the Commission sought to reinforce and deepen social and employment surveillance and coordination within the Semester. This mainly materialized in the introduction of new scoreboards and indicators to monitor employment and social developments, confirming the Commission's highly technocratic approach toward social policy and its continuous faith in numbers as governing tools. For instance, in 2014 the Commission included a number of auxiliary employment and social indicators within the group informing the Alert Mechanism Report of the MIP to complement the only social indicator already existing in that context, which focused on unemployment. ${ }^{132}$ This evolution is set to be bolstered by the adoption of the European Pillar of Social Rights, a document setting out 20 key principles and rights regarding equal opportunities and access to the labour market, fair working conditions and social protection and inclusion that has been proclaimed with much fanfare in November 2017. ${ }^{133}$ According to the AGS 2018, the Pillar should "serve as a point of reference for the further implementation of the European Semester", being "a compass for renewed convergence towards better working and living conditions". ${ }^{134}$ Concretely, the document is set to inspire a further set of indicators aiming at "monitor[ing] "societal progress" and detecting "the most significant

129 European Commission, The Social Dimension of Economic and Monetary Union. Towards Convergence and Resilience, EPSC Strategic Note no. 5, 18 June 2015, 2.

${ }^{130}$ J. Zeitlin and B. Vanhercke, Socializing the European Semester? Economic Governance and Social Policy Coordination in Europe 2020, SIEPS Paper No. 7/2013.

131 S. Sabato, B. Vanhercke and S. Spasova, Listened, but not Heard? Social Partners' Multilevel Involvement in the European Semester, OSE Paper Series, Paper No. 35/2017.

${ }^{132}$ European Commission, Alert Mechanism Report 2014, Brussels, 13 November 2013, COM(2013) 790 final, 10.

133 S. Garben, 'The European Pillar of Social Rights: Effectively Addressing Displacement?', (2018) 14 European Constitutional Law Review 215.

${ }^{134}$ European Commission, Annual Growth Survey 2018, 22 November 2017, COM(2017) 290 final, 3. 
employment and social challenges facing the Member States, the EU and the euro area, as well as progress achieved over time". 135

The introduction of new social indicators in different surveillance and coordination processes has certainly contributed to imbue programmatic documents and CSRs with greater social sensitivity, as demonstrated by the growing number of recommendations that treat social issues not just as factors that should contribute to the attainment of EMU core objectives. For instance, in 2017 the Council recommended Belgium to "ensure that the most disadvantaged groups, including people with migrant background, have equal access to quality education, vocational training, and the labour market", ${ }^{136}$ Spain to "address regional disparities and fragmentation in income guarantee schemes and improve family support, including access to quality childcare" 137 and Ireland to "enhance social infrastructure, including social housing and quality childcare". ${ }^{138}$

It is doubtful whether this evolution actually marks the end of the prioritisation of economic objectives over social ones within the Semester. Indeed, the more 'sociallyoriented' recommendations are still marginal if compared with those that perpetuate the 'traditional' approach. Furthermore, these recommendations perpetuate a vision of social policy that is at odd with the universalistic model that was at the basis of the evolution of the welfare state in the post-war period and that, as seen above, constitutes a key component of Member States' constitutional identity. The recommended reforms place much emphasis on the principles of formal equality, individual responsibility and reduced welfare dependency. ${ }^{139}$ In this context, individuals have to rely first on the market to satisfy their needs, while social safety nets should be targeted and highly selective in their functioning.

\section{National social spaces, financial assistance and conditionality}

\subsection{Intruding into national social spaces by escaping from the EU Treaties (and the} rule of law)

Conditionality is a key feature of all the financial assistance packages and mechanisms that have been adopted to salvage EU Member States in difficulty because of the economic crisis. ${ }^{140}$ This was the case already with earlier balance-of-payments assistance programmes ${ }^{141}$ used to rescue non-Euro States, such as Hungary, ${ }^{142}$ Latvia ${ }^{143}$

${ }^{135}$ Commission Staff Working Document, Social Scoreboard, Brussels, 26.04.2017, SWD(2017) 200 final, 2.

${ }^{136}$ Council Recommendation of 11 July 2017 on the 2017 National Reform Programme of Belgium and delivering a Council opinion on the 2017 Stability Programme of Belgium, OJ C 261 of 09.08.2017, 6.

137 Council Recommendation of 11 July 2017 on the 2017 National Reform Programme of Spain and delivering a Council opinion on the 2017 Stability Programme of Spain, OJ C 261 of 09.08.2017, 35.

${ }^{138}$ Council Recommendation of 11 July 2017 on the 2017 National Reform Programme of Ireland and delivering a Council opinion on the 2017 Stability Programme of Ireland, OJ C 261 of 09.08.2017, 30 .

139 J. Vignon and B. Cantillon, 'Is There a Time for "Social Europe"? Looking Beyond the Lisbon Strategy Paradigm', OSE Opinion Paper No. 9/2012, 5

${ }^{140}$ See, ex multis, A. Baraggia, 'Conditionality Measures within the Euro Area Crisis: A Challenge to the Democratic Principle?', (2015) 4 Cambridge Journal of International and Comparative Law 268; M. Ioannidis M., 'EU Financial Assistance Conditionality after "Two Pack”, (2014) 74 ZaörV 61.

${ }^{141}$ Conditionality was far more lenient and less intrusive in balance-of-payments assistance packages in the 1970s and 1980s: see H.W. Stieber, European Macro-Financial Solidarity Mechanisms 1971-1993: Balance of Payments Assistance between the End of Bretton Woods and the Launch of EMU (2015) available at SSRN: https://ssrn.com/abstract=2544996.

${ }^{142}$ Council Decision 2009/102/EC of 4 November 2008 providing Community medium-term financial assistance for Hungary, OJ L 37 of 06.02.2009, 5-6. 
and Romania, ${ }^{144}$ as well as with regard to the financial package hastily arranged to save Greece in 2010. In the latter case, in May 2010 the Eurogroup stated that stability support could be granted only "on the basis of a programme which has been negotiated with the Greek authorities by the Commission and the IMF, in liaison with the [European Central Bank]". ${ }^{145}$ The same goes for the financial mechanisms created after the eruption of the crisis, such as the European Financial Stabilization Mechanism (EFSM), ${ }^{146}$ the European Financial Stability Facility (EFSF), ${ }^{147}$ established in 2010 as a temporary mechanism to provide financial help to Euro area Member States, and the European Stability Mechanism (ESM). ${ }^{148}$ In particular, Article 12 of the ESM Treaty posits that "the ESM may provide stability support to an ESM Member subject to strict conditionality". Lastly, conditionality was set to play a pivotal role also in the context of the Outright Monetary Transactions announced, but never implemented, by the European Central Bank ('ECB') in 2012. In this context, sovereign bonds purchases had to be subject to respect by the beneficiary State of the policy conditions enshrined in an EFSF or ESM programme. ${ }^{149}$ More recently, it has been established that sovereign bonds purchases under the Public Sector Purchase Programme depend on a positive outcome of the programme review. ${ }^{150}$

The decision to make financial assistance conditional on respect by the beneficiary State of a macro-adjustment programme owes much to the influence exercised by the International Monetary Fund ('IMF') in shaping the EU response to the sovereign debt crisis. ${ }^{151}$ However, conditionality was not just an external imposition: the need to make financial assistance subject to the respect of strict policy requirements was quickly internalized, receiving strong support from some EU Member States and EU institutions alike. This led to the granting of constitutional status to conditionality: in 2011 a new paragraph was added to Article 136 TFEU so as to allow establishment of the European Stability Mechanism, which mandates making "the granting of any required financial assistance under the mechanism [...] subject to strict conditionality". 152

${ }^{143}$ Council Decision 2009/289/EC of 20 January 2009 granting mutual assistance for Latvia, OJ L79 of 25.03/2009, 37-38.

144 Council Decision 2009/459/EC providing Community medium-term financial assistance for Romania, OJ L 150 of 13/06/2009, 8-10.

145 Statement by the Eurogroup, 2 May 2010 available on www.consilium.europa.eu/uedocs/cmsUpload/100502-\%20Eurogroup_statement.pdf

146 Council Regulation (EU) No. 407/2010 of 11 May 2010 establishing a European financial stabilization mechanism, OJ L 118 of 12.05.2010, 1-4.

147 The creation of the EFSF was envisaged in the Decision of the Representatives of the Governments of the Euro Area Member States Meeting within the Council of the European Union, ECOFIN, Brussels, 9 May 2010. Note of the General Secretariat of the Council No. 9614/10.

148 The Treaty establishing the European Stability Mechanism (ESM Treaty) was signed in March 2012. The ESM was inaugurated on 8 October 2012.

${ }^{149}$ Quite remarkably, the Court found that the choice to subordinate the purchases of sovereign bonds to the adoption of far-reaching economic reforms by the beneficiary State did not alter the monetary policy nature of ECB's intervention. See Judgment of 16 June 2015, Gauweiler, C-62/14, paras. 57-58.

${ }^{150}$ Decision (EU) 2015/10 of the European Central Bank of 4 March 2015 on a secondary markets public sector asset purchase programme, OJ L 121 of 14.05.2015, 20-24. See generally C. Kilpatrick, 'Abnormal Sources and Institutional Actions in the EU Sovereign Debt Crisis - ECB Crisis Management and Sovereign Debt Loans', in M. Cremona and C. Kilpatrick (eds), EU Legal Acts: Challenges and Transformations (Oxford University Press, 2018), 70-105; A. Viterbo, 'Legal and Accountability Issues Arising from the ECB's Conditionality', (2016) 1 European Papers 501.

${ }^{151}$ F. Seitz and T. Jost, The Role of the IMF in the European Debt Crisis, HAW im Dialog - Weidener Diskussionpapiere No. 32/2012.

${ }^{152}$ European Council Decision 2011/199/EU of 25 March 2011 amending Article 136 of the Treaty on the Functioning of the European Union with regard to a stability mechanism for Member States whose 
Conditionality represents a quantum leap in the transformative process described in previous sections. It gives EU institutions an unprecedented capacity to intrude into national social spaces and, hence, to subordinate the exercise of social functions to the pursuit of economic objectives. This transformation represents an "extreme case of vertical $[\ldots]$ integration in the policy arena, which goes well beyond what is generally meant by Europeanization, and cannot be captured through multilevel governance heuristic". ${ }^{153}$

Operationally, the transformation is premised upon the escape ${ }^{154}$ from EU Treaties and, as denounced by many commentators, the "degradation of basic legal values" underpinning the EU legal architecture. ${ }^{155}$ Indeed, this allows supranational institutions to engage in close surveillance and micromanagement of social and labour policies to an extent that goes well beyond the limits set by the principle of conferral and the other Treaty provisions safeguarding the European social dimension. ${ }^{156}$ Acting outside the EU legal order, creditors and their representatives can fully exploit the asymmetry of power that underpins the relationship between a party that controls the financial resources and another that badly needs those resources to avoid default.

The escape from EU law, its logic and guarantees is all the more evident in those cases where EU institutions and, in particular, the ECB resorted to informal tools, such as secret letters, to put pressure on some Member States in order to force them into socially painful structural adjustment programmes. This approach, bordering on blackmail, has been adopted in the case of Italy, which, in August 2011, received a letter ${ }^{157}$ from the then President of the ECB and the then Governor of the Italian Central Bank detailing a list of measures that it had to take and even the legal instruments that it had to use. The adoption of these reforms was considered a condition to benefit from the purchase of sovereign debt paper on the secondary market in the context of the Securities Market Programme, although the letter did not make this link explicit. The same line of action has also been followed with Spain and, although using other forms of pressure, with Ireland, ${ }^{158}$ Cyprus ${ }^{159}$ and Greece. ${ }^{160}$

currency is the euro, OJ L 91 of 06.04.2011, 1-2. See De Witte B. (2011), The European Treaty Amendment for the Creation of a Financial Stability Mechanism, SIEPS, 1-6.

${ }^{153}$ S. Sacchi, 'Conditionality by Other means: EU Involvement in Italy's Structural Reforms in the Sovereign Debt Crisis’, (2015) 13 Comparative European Politics 77.

${ }^{154}$ Baraggia, above, n. 140, at 274

${ }^{155}$ Menéndez, above, n. 8, at 74-78; C. Kilpatrick, 'On the Rule of Law and Economic Emergency: The Degradation of Basic Legal Values in Europe's Bailouts', (2015) Oxford Journal of Legal Studies 1; F. Munari, 'Crisi dell'Euro e crisi delle regole: Rule of Law o ragion politica? Il diritto dell'Unione europea dinanzi a nuove sfide', in O. Porchia (ed.), Governance economica europea. Strumenti dell'Unione, rapporti con l'ordinamento internazionale e ricadute sull'ordinamento interno (Giappichelli, 2015), 33-56.

${ }^{156}$ Ioannidis, above, n. 140, at 63; A. Koukiadaki, 'The Legacy of Economic Crisis for Labour Law in Europe', in Bogg, Costello, Davies, above, n. 44, at 83-84.

157 See http://www.corriere.it/economia/11_settembre_29/trichet_draghi_inglese_304a5fle-ea5911e0-ae06-4da866778017.shtml?refresh_ce-cp. See Sacchi, above, n. 153, at 81- $\overline{8} 8$.

${ }^{158}$ In this case, the ECB played a key role in forcing the State to enter a structural adjustment programme to be negotiated with the Troika. In a letter of 15 October 2010, Trichet reminded the then Irish Minister of Finance of the ECB Governing Council's powers and discretionality in applying collateral rules and in setting limits to ELA, In a subsequent letter of 19 November 2010, Trichet was even clearer on this point. He stated that "[i]t is the position of the Governing Council that it is only if we receive in writing a commitment from the Irish Government vis-à-vis the Eurosystem on the four following points that we can authorize further provision of ELA to Irish financial institutions: 1) The Irish government shall send a request for financial support to the Eurogroup; 2) The request shall include the commitment to undertake decisive actions in the areas of fiscal consolidation structural reforms and financial sector restructuring, in agreement with the European Commission, the IMF and the ECB [...]". 
Unfortunately, the same trait also characterises explicit conditionality. Indeed, the rules governing the definition, approval and monitoring of the conditions attached to financial assistance packages have a "mixed legal parentage"161 that combines international agreements, EU legal acts and other documents, such as Memoranda of Understanding ('MoU'), whose legal nature is contested and that some consider as not even creating legally binding commitments. ${ }^{162}$ Traditionally, the dominant view has been that these provisions fall outside the EU legal framework.

This view has been endorsed also by the Court, which has constantly rejected all the claims brought by private applicants seeking the annulment of acts addressed to a Member State in the context of a financial assistance programme. A recent and fitting example is the Ledra case, ${ }^{163}$ concerning the ESM intervention to assist Cyprus. ESM financial assistance, which lasted from 2013 to 2016, was granted on the back of a macro-economic adjustment programme set by a MoU negotiated between the Troika and the Cypriot authorities. Negotiations started in 2012 and ended in April 2013, when the MoU was signed by the Commission on behalf of the ESM, the Central Bank of Cyprus and the Minister of Finance of Cyprus. In the meanwhile, the Cypriot authorities put the two largest Cypriot banks into resolution and provided for the recapitalisation of one of them, at the expense of uninsured depositors, shareholders and bondholders. Some of them, after having seen a substantial decrease in the value of their deposits, turned to the EU General Court, seeking annulment of the parts of the MoU providing for the restructuring of the banks. The General Court ${ }^{164}$ swiftly rejected the claim, pointing to the fact that the MoU had been adopted by the Republic of Cyprus and the ESM and, thus, because it was not an act of an EU institution, body, office or agency, its legality could not be reviewed under Article 263 TFEU.

The disconnection between bailout measures and the EU legal framework lies at the basis of the decisions of the Court rejecting the requests for preliminary rulings submitted by national courts and, in that context, excluding the applicability of the EU Charter on Fundamental Rights ('the Charter') to austerity measures. ${ }^{165}$ This is what

Unsurprisingly the Irish Government bowed to pressure, formally asking for financial assistance on the 20 November 2010.

${ }^{159}$ In a Decision of 21 March, the ECB Governing Council declared that it would reject a request of Emergency Liquidity Assistance by Cyprus' National Central Bank unless “an EU/IMF programme is in place that would ensure the solvency of the concerned banks". Also in this case, the pressure put by the ECB was enough to convince the State.

${ }^{160}$ On 28 June and 6 July 2015, the ECB Governing Council twice decided to reject the request by the Greek National Central Bank to raise the Emergency Liquidity Assistance, forcing Greek authorities to impose a bank holiday and capital control. These decisions did not refer at all to the breakdown of the negotiations between Greece and EU institutions on the Third Assistance Package. However, it is telling that the very day on which the Tsipras Government secured a Parliamentary vote on the measures that it pledged to make to obtain assistance from the EU, the ECB raised the ELA by 900 million euros.

${ }^{161}$ C. Kilpatrick, 'Are the Bailouts Immune to EU Social Challenge Because They Are Not EU Law?, (2015) 10 European Constitutional Law Review 393, 409. See also C. Kilpatrick, 'The EU and its Sovereign Debt Programmes: The Challenges of Liminal Legality', (2017) 70 Current Legal Problems 337.

162 This position has been held, in a rather contradictory way, by AG Bot in Florescu, where he first held that the MoUs is "is an act of the EU institutions for the purposes of Article 267(b) TFEU and may thus be interpreted by the Court" and, subsequently, that it "does not produce binding legal effects" (Opinion of AG Bot of 21 December 2016, Florescu, case C-258/14, paras. 47-53).

163 Judgment of 20 September 2016, Ledra Advertising et al., Joined cases C-8/15 to C-10/15 P. See R. Repasi, 'Judicial Protection Against austerity measures in the euro area: Ledra and Mallis', (2017) 54 Common Market Law Review 1123.

${ }^{164}$ Order of 10 November 2014, Ledra Advertising Ltd, T-289/13, paras. 56-63.

${ }^{165}$ In some cases this was also due to poorly drafted orders by the referring national courts, which failed to properly highlight the linkages between national reform measures and the EU legal order. On 
happened, for instance, in Sindicato dos Bancarios do Norte, ${ }^{166}$ a case concerning the Portuguese bailout package. ${ }^{167}$ Here the Court found that the cuts to public sector wages and the suspension the payment of bonuses had not been adopted by the Portuguese authorities to implement EU law and thus fell outside the scope of application of the Charter according to Article 51 thereof. The approach has been rightly criticized for being unduly restrictive if compared with the Court's previous case-law and for disregarding the strong linkages existing between bailout programmes and EU law. ${ }^{168}$ The Court's position seems all the more untenable ${ }^{169}$ after the entry into force of Regulation no. 472/2013, which requires Eurozone States requesting, or already "in receipt"170 of, financial assistance to "prepare, in agreement with the Commission, acting in liaison with the ECB and, where appropriate, with the IMF, a draft macroeconomic adjustment programme" by the Commission.

\subsection{National social spaces as adjustment variables in structural adjustment} programmes

Many of the conditions attached to financial assistance programmes touch upon key aspects of national social spaces, pointing to the reduction of social expenditure, the modernisation of social protection systems or the reform of labour market regulation in a way that is fully coherent with the approach followed by CSRs in the context of the European Semester. This does not occur by mere coincidence, since both the ESM Treaty $^{172}$ and Regulation (EU) No. 472/2013 explicitly require structural adjustment programmes to be compatible with economic policy coordination measures and even aiming at "broadening, strengthening and deepening the required policy measures. ${ }^{173}$ As explained by the Court in Pringle, "the purpose of the strict conditionality [...] is to ensure that the ESM and the recipient Member States comply with measures adopted by the Union in particular in the area of the coordination of Member States' economic policies, those measures being designed, inter alia, to ensure that the Member States pursue a sound budgetary policy". ${ }^{174}$

However, conditionality also serves deterrent purposes, which are largely absent in economic coordination efforts. As pointedly observed by Schepel, "States will have to be deterred from pursuing unsound budgetary policies by the prospect of having to live

this issue see C. Barnard, The Charter, the Court - and the Crisis, University of Cambridge Legal Studies Research Paper Series, Paper No. 18/2013, 12.

166 Order of 7 March 2013, Sindicato dos Bancarios do Norte, C-128/12, paras. 11-12.

167 Council Implementing Decision 2011/344/EU of 30 May 2011 on granting Union financial assistance to Portugal, OJ L159 of 17.06.2011, 88-92.

168 S. Peers, 'Towards a New Form of EU Law? The Use of EU Institutions Outside the EU Legal Framework', (2013) 9 European Constitutional Law Review 37.

${ }^{169}$ Kilpatrick (2015), above, n. 161, at 398-406. See also F. Rödl and S. Callsen, 'The Struggle for Union Rights under the Euro and the Dialectics of Social Integration', in C. Joerges, C. Glinski (eds), The European Crisis and the Transformation of Transnational Governance: Authoritarian Managerialism versus Democratic Governance (Hart Publishing, 2014), 117.

${ }^{170}$ Article 16.

171 Article 7.

${ }^{172}$ Article 13(3) ESM Treaty reads as follows: "The MoU shall be fully consistent with the measures of economic policy coordination provided for in the TFEU, in particular with any act of European Union law, including any opinion, warning, recommendation or decision addressed to the ESM Member concerned".

${ }^{173}$ Article 7(1) Regulation (EU) No. 472/2013.

${ }^{174}$ Pringle, para. 72. 
through the same amount of pain and misery inflicted on States assisted by the ESM". ${ }^{175}$ Conditionality therefore aims to correct the distortion of Member States' incentives, reducing the risk of moral hazard by preventing some of them from persevering in unsound fiscal behaviours in the belief that others will pay the costs. ${ }^{176}$ From that perspective, conditionality fits perfectly with the tale "that attributes the euro zone malaise to lazy southern grasshoppers begging for money from the productive, disciplined and ant-like northerners". ${ }^{177}$ This imagery, which has been eagerly embraced by creditor countries' politicians to please their disgruntled electoral bases, provides an apparently sound justification for cutting back on Southern States' excessively generous welfare systems and for asking them to do their homework in order to restore their competitiveness. But this is to forget that their problems are mainly due to structural imbalances that, as seen above, are inherent in the EMU as it stands.

Similarly to what was observed with regard to the Semester, socially relevant conditions can be divided into two categories on the basis of their main objective. A first set of conditions aims at contributing to the reduction of sovereign debt through cuts to social outlays. The second group of conditions centres on restoring beneficiary States' external competitiveness, mainly by fostering internal devaluation.

Targeting social spending as the main path to the reduction of public debt has been a feature of all rescue packages from the outset. In the case of Greece, for instance, the first Economic Adjustment Programme of 2010 envisaged cuts in health care expenditure amounting to more than 2 billion euros by 2015 and cuts in social benefits amounting to more than 5 billion euros by the same year. ${ }^{178}$ The Memorandum of Economic and Financial Policies of the second Economic Adjustment Programme (2012) plainly admitted that most of the cuts imposed by the "bold structural spending reforms" "will need to fall on social transfers". ${ }^{179}$ The same approach prevailed also in the documents detailing the conditions attached to the Third Economic Adjustment Programme, approved in August 2015. In this context, Greek authorities committed to fully implementing pensions reforms in order to target savings of around 0.25 percent of GDP in 2015 and 1 percent of GDP in 2016.

The second group of socially relevant conditions aims at restoring beneficiary States' external competitiveness through the adoption of structural reforms that can make welfare institutions and, above all, labour markets work in a more growth-friendly way. The objective has been mostly pursued by reducing wages and other labour costs,

175 H. Schepel, 'The Bank, the Bond, and the Bail-Out: On the Legal Construction of Market Discipline in the Eurozone', (2017) 44 Journal of Law and Society 79, 88.

176 On the contested notion of moral hazard see B. Hale, 'What's so Moral About Moral Hazard?', (2009) 23 Public Affairs Quarterly 1.

177 P. Tsoukala, 'Eurozone Crisis Management and the New Social Europe', (2013) 20 Columbia Journal of European Law 31, 37-38.

178 Annex I of Council Decision 2011/734/EU of 12 July 2011 addressed to Greece with a view to reinforcing and deepening fiscal surveillance and giving notice to Greece to take measures for the deficit reduction judged necessary to remedy the situation of excessive deficit, OJ L 296 of 15 November 2011, 38 amended by Council Decision 2011/791/EU of 8 November 2011, OJ L 320 of 03.12.2011, 28, Council Decision 2012/211/EU of 13 March 2012, OJ L 113 of 24.04.2012, 8 and Council Decision 2013/6/EU of 4 December 2012, OJ L 4 of 04.01.2013, 40-45.

179 Published in European Commission (2012), The Second Adjustment Programme for Greece. March 2012, Occasional Paper 94, 97. To this end, Greece undertook to reduce the public sector wage bill, so as to generate 1.5 percent of GDP in savings by 2015, as well as to reform the pension systems, reduce healthcare spending and to amend the social benefit programmes, in order to "realize in total around 4 percent of GDP in additional savings". These savings were to be achieved by reforming the special wage regimes, a drastic reduction of personnel (firing 150,000 public employees in the period 2011-2015) and imposing strict controls on hiring. See Greece: Memorandum of Economic and Financial Policies, in European Commission, The Second Economic Adjustment Programme for Greece, 97-98. 
making individual and collective dismissals easier, forcing Member States to revise (or even dismantle) their wage-setting arrangements by, inter alia, giving precedence to individual over collective bargaining. All of this should foster internal devaluation, which, in a monetary union where currency devaluation is no longer an option and where there is not centralised fiscal capacity, has seemingly become the only adjustment variable to respond to structural imbalances. ${ }^{180}$

This approach informed all the Greek assistance packages. For instance, the MoU of March 2010 established that "[i]n dialogue with social partners, the government proposes and parliament adopts legislation to reform wage bargaining system in the private sector, which should provide for a reduction in pay rates for overtime work and enhanced flexibility in the management of working time. Allow local territorial pacts to set wage growth below sectoral agreements and introduce variable pay to link wages to productivity performance at the firm level". ${ }^{181}$ The Second Adjustment Programme was even more penetrating on this point, since "the outcome of the social dialogue to promote employment and competitiveness fell short of expectations". Therefore, the Greek Government undertook to adopt, prior to the disbursement of the financial support, a series of measures, such as a 22 percent reduction of minimum wage, the introduction of sub-minimum wages for young people - ten percent less than the normal one - and the reform of wage-setting mechanisms, leading to an "overhaul of the national general collective agreement". ${ }^{182}$ The Third Adjustment Programme, approved in 2015, envisaged the launch of a consultation process touching upon several key aspects of the labour market. The process should lead to the reform of the rules governing collective dismissal, industrial action and collective bargaining, so as to bring them "in line with the best practice in the EU". ${ }^{183}$ For greater certainty, the document added that, in any case, "[c]hanges to labour market policies should not involve a return to past policy settings which are not compatible with the goals of promoting sustainable and inclusive growth". ${ }^{184}$

Similarly, Portuguese authorities agreed to reform employment protection legislation, mainly by cutting severance payments and broadening the cases of permitted individual dismissals, as well as "promote wage developments consistent with the objectives of fostering job creation and improving firms' competitiveness with a view to correcting macroeconomic imbalances". ${ }^{185}$ Furthermore, seeking to align wage developments with productivity, the Portuguese Government committed to decentralize the bargaining process by strengthening the role of firm-level agreements vis-à-vis sectoral collective ones.

5.3. Attempts at socializing structural adjustment programmes: little improvement, so far

${ }^{180}$ See Menéndez, above, n. 8, at 68-70.

${ }^{181}$ At 68.

${ }^{182}$ At $146-147$.

${ }^{183}$ A reference to these standards can be found also in Article 2(5) Council Implementing Decision (EU) 2015/1411 of 19 August 2015 approving the Macroeconomic Adjustment Programme for Greece, OJ L 219 of 20.08.2015, 12.

${ }^{184}$ Memorandum of Understanding between the European Commission acting on behalf of the European Stability Mechanism and the Hellenic Republic and the Bank of Greece, 19 August 2015, pp. 21-22.

185 Portugal. Memorandum of Understanding on Specific Economic Policy Conditionality, in European Commission, The Economic Adjustment Programme for Portugal, Occasional Paper 79, June 2011, 80-83. 
The harsh - but largely well-deserved - criticisms levelled against the one-sided approach that has characterized conditionality in the context of financial assistance programmes have not fallen on totally deaf ears in Brussels. Over the years, there have been some attempts to imbue structural adjustment programmes with greater social sensitivity. At present, these developments seem largely inadequate, failing, inter alia, to bring to an end the subordination of national social spaces' reforms to the logics and aims of the EMU.

A first example to be considered is the regulation establishing a single conditionality procedure applicable to all financial assistance mechanisms. In particular, Article 7 of Regulation (EU) No. 472/2013 establishes that, when a Member State requests financial assistance, the draft macroeconomic adjustment programme has to take "into account the practice and institutions for wage formation and the national reform programme of the Member State concerned", as well as to "fully observe Article 152 TFEU and Article 28 of the Charter". Moreover, President Juncker's apparently sought to lend its political support to this evolution by making it one of the key aspects of its manifesto. The Political Guidelines for the new Commission established that "in the future, any support and reform programme [should go] not only through a fiscal sustainability assessment; but through a social impact assessment as well", so as to ensure that "the social effects of structural reforms [are] discussed in public". ${ }^{186}$

So far all these attempts have led to only marginal variations on the main theme, leaving substantially untouched the unequal relationship between social objectives and economic ones in this context. An example in this regard is the adoption, prior to the Greek Adjustment Programme of 2015, of the Assessment of the Social Impact of the new Stability Support Programme for Greece, a document purporting "to show how the design of the stability support programme has taken social factors into account". ${ }^{187}$ Despite its title, the document fails to properly engage with the Greek social disaster, as well as to explore its root causes and its relationship with the Troika's recipes. Instead, it simply praises the reforms that Greek governments have adopted over the last few years in fields like pensions, tax policy, labour market, job creation and product markets, urging the need to move further ahead along this path. Indeed, as the very last sentence of the document makes clear, "if implemented fully and timely, the measures envisaged under the new ESM stability support programme will bring Greece back to stability and growth, in a financially and socially sustainable way. In so doing, the burden of adjustment is distributed as equitably and as fairly as possible across society, and adequately takes account of the most pressing social needs and challenges in Greece". ${ }^{188}$

Therefore, it is hardly a surprise to discover that the content of recent MoUs is very much in line with their predecessors. The much-heralded move toward a more sociallyconscious conditionality is confined to a few marginal elements having little bearing on its core content and structure. For instance, on the one hand, the August 2015 Memorandum for Greece explicitly recognized the need for greater social justice, urging the Greek Government to "roll out a basic social safety net in the form of a Guaranteed

${ }^{186}$ A New Start for Europe: My Agenda for Jobs, Growth, Fairness and Democratic Change. Political Guidelines for the next European Commission, 15 July 2014. On the inconsistencies of the monitoring activities carried out to measure conditionality policy's impact on the vulnerable see R. O'Gorman, 'The Failure of the Troika to Measure the Impact of the Economic Adjustment Programmes on the Vulnerable', (2017) 44 Legal Issues of Economic Integration 265.

187 European Commission Staff Working Document, Assessment of the Social Impact of the new Stability Support Programme for Greece, Brussels, 18.08.2015, SWD(2015) 162 final, 4.

${ }^{188}$ Ibidem, 20. 
Minimum Income" 189 and praised the adoption of some measures aimed at supporting the most vulnerable part of the population. ${ }^{190}$ On the other hand, the document still closely adhered to the idea that the reform of national social spaces should, first of all, pursue economic and fiscal objectives, such as "controlling public expenditure". ${ }^{191}$ Likewise, the 2016 Supplemental MoU for Greece put much emphasis on the need to reform the social safety nets, ${ }^{192}$ but it then made clear that the main objective to be achieved through this comprehensive reform was to "generate savings of $0.5 \%$ annually". ${ }^{193}$ Furthermore, the document contained a prescription urging Greek authorities to "compensate for the cost of the Council of State ruling (equivalent to 2 percent of GDP) on some aspects of the previous pension reforms". ${ }^{194}$ This condition refers to a 2015 decision by the Greek Supreme Court finding that the 2012 pension cuts breached the Greek Constitution and the European Convention of Human Rights ('ECHR') for depriving pensioners of their right to a decent life. This is a very troubling example of the depth of the transformation of the European constitutional constellation: far from representing a cornerstone of the so-called European social model, the protection of social rights is now seen as a cost that needs to be compensated.

A second evolution worth considering is the Court's renewed commitment to the protection of fundamental rights in the context of structural adjustment programmes. As seen above, the Court went through a long period in which it seemed to adhere fully to the idea that bailout measures were immune from judicial scrutiny at supranational level. ${ }^{195}$ However, there are now some tentative signs of developments in the opposite direction. An example in this regard is the Florescu judgment of June 2017. The case concerned a Romanian law of 2009 that prohibited combining a pension with an income for activities carried out in a public institution. Anyone in such position had to either ask for the suspension of the pension or relinquish the paid job. The law had been adopted in order to fulfil the obligations arising under the MoU negotiated by the Romanian Government with the Commission as a condition to obtain financial assistance from the EU. Three retired judges, teaching at the law faculty of Sibiu, challenged the measure, which, in their view, violated several of their rights. The Court of Appeal decided to stay proceedings and raise a number of preliminary questions. In 2011 and 2012 the Court dismissed two requests concerning similar measures adopted by Romanian

189 At 4.

190 This praise seems somewhat paradoxical, especially if one considers donors' hostility to the adoption of these measures when they were proposed by the newly-elected Tsipras Government.

191 Memorandum of Understanding between the European Commission acting on behalf of the European Stability Mechanism and the Hellenic Republic and the Bank of Greece, 19 August 2015, 13 and 17.

${ }^{192}$ Stressing that "[a] fairer society will require that Greece improves the design of its welfare system in line with EU best practices, so that there is a genuine social safety net which targets scarce resources to those in most need"

193 Supplemental Memorandum of Understanding, 16 June 2016, 19. The same applies to the 2017 Supplemental MoU with regard to health care. After calling for a reform of the healthcare sector that should aim to strengthen "universal, equal and effective care", the conditions focus exclusively on the "rationalization of health expenditure", "execution of claw backs and regular audit", "measures to improve the financial management and cost effectiveness of hospitals" and "reducing pharmaceuticals spending through generic penetration and price reduction" (Supplemental Memorandum of Understanding (Second Addendum to the memorandum of Understanding) between the European Commission acting on behalf of the European Stability Mechanism and the Hellenic Republic and the Bank of Greece, 5 July 2017, 20-23).

194 Ibidem, 4.

195 On the role of the Court in this context see generally O. Porchia, 'Il ruolo della Corte di Giustizia dell'Unione europea nella governance economica europea', (2013) Il diritto dell'Unione europea 593. 
authorities on the basis of the very same law, finding "an easy escape route"196 in poorly drafted orders for reference that failed to highlight the connection between national measures and EU law. Conversely, in Florescu the Court declared its competence to rule on the compatibility between Romanian austerity measures and EU law provisions protecting fundamental rights. To this end, it found that the MoU is reviewable under Article 267 TFEU, since it is mandatory and "constitutes an act of an EU institution". 197 This was the first time, nine years after the first financial assistance programme was launched, in which the Court took a clear position on this issue. Yet, the implications of this finding need to be assessed against the specificities of Romania's assistance programme. Indeed, the latter was based on Article 143 TFEU, which empowers the EU to financially assist non-euro States facing difficulties as regards their balance of payments. This means that the MoU at issue stems from EU law, having being adopted on the basis of Article 143 TFEU and Regulation (EC) No. 332/2002. ${ }^{198}$ As a consequence, the Court had no difficulty in finding that the Charter was applicable to the case at hand. It pointed to the fact that Romanian authorities were implementing EU law when adopting measures that aimed at realizing the objectives set forth in the MoU. In the process, the Court excluded, by correctly referring to its previous case-law, that the existence of a margin of discretion for national authorities in deciding what measures were to be adopted could in any way call this analysis into question. ${ }^{199}$

What remains to be seen is whether Florescu is a sign of a broader change of attitude by the Court or whether the latter will stick to its strict interpretative approach when deciding on the applicability of the Charter in cases where bailout conditions are set by documents whose main legal basis lies outside the EU legal framework. This could have the effect of even further distancing the possibility of bringing structural adjustment programmes fully under EU law, as recently proposed by the Commission. ${ }^{200}$ The Court has been recently given the chance to shed more light on this issue, but it purposely eluded it. The case concerned the reduction of the salaries of Portuguese Court of Auditors' judges resulting from a law adopted in 2014 that scaled down the remuneration of many categories of public servants, thereby fulfilling one of the conditions contained in the structural adjustment programme negotiated with the Troika. In the national proceeding, the claimants sought to have the measure annulled, arguing that it contrasted with the principle of judicial independence as enshrined in Article 19 TEU and in Article 47 of the Charter. The referring judge - the Supremo Tribunal Administrativo - asked the Court whether these EU provisions must be interpreted in the sense of precluding the adoption of measures such as the contested ones. In his Opinion, AG Saugmandsgaard $\varnothing \mathrm{e}^{201}$ concluded that the Portuguese measure "constitutes an implementation of provisions of EU law, within the meaning of Article 51 of the Charter". ${ }^{202}$ The conclusion seemingly pointed to the existence of a sufficiently strong linkage between the contested measures and the EU legal order. In particular, the AG posited, without spelling it out clearly, that the reduction of salaries

196 Barnard, above, n. 165.

197 Judgment of 13 June 2017, Florescu, C-258/14, para. 35. See A. Miglio, 'La condizionalità di fronte alla Corte di Giustizia', (2017) Diritti umani e diritto internazionale 763.

198 Council Regulation (EC) No. 332/2002 of 18 February 2012 establishing a facility providing medium-term financial assistance for Member States' balances of payments, OJ L 53 of 23.202.2012, 1-3.

${ }^{199}$ Para. 48. See generally Kilpatrick (2015), above, n. 161, at 412-415.

${ }^{200}$ European Commission, Proposal for a Council Regulation on the Establishment of the European Monetary Fund, COM(2017) 827 final, 06.12.2017.

${ }^{201}$ Opinion of AG Saugmandsgaard Øe of 18 May 2017, Associação Sindical dos Juizes Portugueses, C-64/16.

202 Para. 53. 
constituted a measure adopted to comply with conditions referred to also in EU legal acts, such as Council implementing decisions. Unfortunately, the Court felt no need to engage with this issue, focusing exclusively on Article 19 TEU, which has a broader scope of application than the Charter. This provision requires Member States to ensure effective legal protection "in the fields covered by Union law" and not just when they are implementing EU law. ${ }^{203}$

The Court had already opened up another judicial avenue for the protection of fundamental rights in non-EU based structural adjustment programmes. In particular, it found that individuals can bring a non-contractual liability action against the EU when its institutions, even if acting outside the EU legal framework, violate fundamental rights. The question of whether EU institutions are bound to comply with EU law when acting outside the EU order had been left unanswered in Pringle. There the Court focused exclusively on the position of Member States, reiterating that they are not bound by the Charter "when they establish a stability mechanism such as the ESM", since they are not implementing Union law. ${ }^{204}$ Conversely, in the above-mentioned Ledra judgment the Court tried to fill this gap by declaring the admissibility of an action for damages brought by a number of Cypriot investors against the EU, pointing to the role played by the Commission in the negotiation and conclusion of the MoU. ${ }^{205}$ In particular, starting from the premise that participation in the ESM activities cannot alter the powers conferred to the institution by the Treaties, the Court established that "the Commission retains, [...] within the framework of the ESM Treaty, its role of guardian of the Treaties as resulting from article 17(1) TEU". For this reason, it is bound to "refrain from signing a memorandum of understanding" when "it doubts" its consistency with EU law. ${ }^{206}$ To be sure, the judgment represents a welcome novelty, at least from the perspective of aggrieved individuals, because it is the first case where the Court has finally admitted the possibility that bailout measures are amenable to some form of judicial review in the EU legal order. However, the action for damages is a narrow avenue for the judicial protection of fundamental rights and it is doubtful whether it can properly safeguard national social spaces' objectives and functions in the context of structural adjustment programmes. Indeed, not any violation of a EU norm can be challenged through this type of action. ${ }^{207}$ According to a well-established case law, EU non-contractual liability arises only when there is an actual damage caused by a sufficiently serious breach of a rule of Union law that confers rights on individuals. ${ }^{208}$ Therefore, violations of other relevant rules - such as, for instance, the principle of conferral or the social clause - are hardly amenable to judicial scrutiny under this action.

203 Judgment of 27 February 2018, Associação Sindical dos Juizes Portugueses, C-64/16. The judgment found that the Portuguese measures did not violate the principle of judicial independence, which, according to the Court, is a component of the principle of effective judicial protection codified by Article 19 TEU.

${ }^{204}$ Judgment of 27 November 2012, Pringle, C-370/12, para. 180. See critically P. Craig, 'Pringle and Use of EU Institutions outside the EU Legal Framework: Foundations, Procedure and Substance', (2013) 9 European Constitutional Law Review 263.

205 A. Spagnolo, 'The Loans of Organs Between International Organization as "Normative Bridge": Insights from Recent EU Practice', (2017) 26 Italian Yearbook of International Law 171; S. Vezzani, 'Sulla responsabilità extracontrattuale dell'Unione europea per violazione della Carta dei diritti fondamentali: riflessioni in margine alla sentenza della Corte di giustizia nel caso Ledra Advertising', (2017) 100 Rivista di diritto internazionale 154.

${ }^{206}$ Ledra, paras. 58-59.

${ }^{207}$ See generally K. Gutman, 'The Evolution of the Action for Damages Against the European Union and its Place in the System of Judicial Protection, (2011) 48 Common Market Law Review 710.

208 Judgment of 10 July 2003, Fresh Marine Company, C-472P, para. 25. 
Furthermore, in all these early cases the Court has adopted a rather deferential standard of review to assess the compatibility of national structural adjustment measures with the Charter's provisions. The judges seem to have wholeheartedly followed the line of action proposed by Barnard, who argued that, instead of putting these measures outside the reach of EU law, the Court should address the merit of the cases, granting a wide margin of discretion to decision-makers in order to preserve their autonomy of action. ${ }^{209}$

In Florescu, for instance, the Court found that the contested measure did not violate claimants' right to property as enshrined in Article 17 of the Charter, since it "is capable of attaining the general interest objective pursued and is necessary to attain that objective". While this conclusion is convincing in light of the caution of the measure and the content of the claim, what is less reassuring, especially in a forward looking perspective, is the way in which the Court reached it. Indeed, the whole reasoning hinges upon the wide margin of discretion that national authorities have "when adopting economic decisions", since they are those "in the best position to determine the measures likely to achieve the objective pursued". ${ }^{210}$ Such a highly deferential approach is at the vanishing point of judicial scrutiny, putting the Court in the spectator's seat while national authorities are free to run the show as they wish. What justifies the granting of a wide margin is "the particular economic context", which needs to be confronted by "reducing public sector wage costs and [...] reforming the pension system". ${ }^{211}$ The Court thus seems to share the sense of inevitability that pervades the adoption of austerity measures and is a defining feature of the technocratic approach prevailing in that context. This makes the pursuit of the objectives set in the MoU a 'trump card' that can prevail over any other competing aim.

\section{Conclusion}

The risk that national social spaces could be a victim of the EMU was clear even before its creation. With the eruption of the Eurozone crisis and the ensuing reform of economic governance mechanisms this risk fully materialized. These reforms purported to enhance the capacity of supranational institutions to intrude into national social spaces, enabling them to exercise policy formulation, supervision and guidance on issues, such as pensions or wage levels, that fall squarely within Member States' exclusive competence. This occurred neither through a reform of Treaty's rules on the allocation of competences, nor by nominally violating them. In the case of the European Semester, the strengthening of supranational institutions' capacity of intervention derived from the creation of a hybrid framework allowing the Commission to gain leverage in sectors covered by soft coordination processes while relying on the threat of hard sanctions. As regards bailout programmes, the transformation came about through recourse to non-EU law instruments so as to circumvent the limits set by the Treaties and the Charter.

The reduction of Member States' autonomy in the social sphere is functional to the stabilization of the EMU. Therefore, national social spaces have been treated either as a cost to be reduced in order to balance Member States' budgets or as a factor that should contribute to increasing their external competitiveness. This happened in the European Semester and, in particular, in its early cycles, when most of the CSRs addressing social issues aimed at fiscal consolidation, labour market deregulation or wage reduction. Conditionality policy in the context of financial assistance programmes was a quantum

${ }^{209}$ Barnard, above, n. 165, at 13-14.

${ }^{210}$ Florescu, para. 57.

${ }^{211}$ Id., paras 56-57. 
leap forward in this regard by stringently subordinating national social spaces to EMU logics and objectives. MoUs' prescriptions paid little, if any, attention to the effects of this one-sided approach upon national social spaces' capacity to pursue their core objectives, such as promoting dignity, autonomy and social justice.

The above-described evolution has a severe impact on one of the defining features of the EU constitutional identity, as well as one of the main sources of legitimacy of the European integration process. The importance of national social spaces in this regard had already emerged during the negotiations leading to the adoption of the Treaty of Rome, where the creation of an integrated market at supranational level was conceived as a way to strengthen social spaces at national level. The demise of the original compromise led to a rethinking of the relationship between the 'economic' and the 'social' in the EU legal order. The new configuration, enshrined in the Treaty of Lisbon, put these two sets of objectives on the same footing, imposing that conflicts and tensions should be resolved by finding a workable balance between the two, rather than ranking them hierarchically. Conversely, the transformation of national social spaces in adjustment variables within the EMU determines the systematic prioritisation of a restricted number of economic objectives over social ones, in a way that is at odds with the EU constitutional identity.

It is therefore necessary to halt and reverse this transformation by recreating at national level the political space for an autonomous, and democratically legitimate, social policy. To be sure, this is not a call for a return to the stark division between the social sphere and the economic sphere. The original compromise is long gone and clearly incompatible with the very existence of a monetary union. However, it is urgent to emancipate national social spaces from their role of shock absorbers within the EMU and to open up policy space for autonomy and diversity in the social domain. This necessarily entails the creation of a centralised fiscal capacity to finance budgetary transfers $^{212}$ across the Member States of the Euro area that should be made available beyond "the suffocating conditionality requirements contemplated today". 213 Furthermore, there is the need to deal with the so-called "competition trap", ${ }^{214}$ by setting a minimum floor of social and labour standards so to halt the dangerous race to the bottom and, thus, to properly deal with the legitimacy crisis currently affecting the European integration process. If evaluated from that angle, recent attempts at resocialising economic governance mechanisms are far too timid and manifestly unfit for the purpose.

212 See, for instance, R. Repasi, Legal Options and Limits for the Establishment of a European Unemployment Benefit Scheme (Publication Office of the European Union, 2017).

${ }^{213}$ S. Giubboni, 'Europe's Crisis-Law and the Welfare State - A Critique', (2015) 6 Comparative Law Review 5, 13. See also S. Deakin and A. Koukiadaki, 'The Sovereign Debt Crisis and the Evolution of Labour Law in Europe', in N. Countouris and M. Freedland (eds), Resocialising Europe in a Time of Crisis (Cambridge University Press, 2013), 181. 81.

${ }^{214}$ L. Gallino, La lotta di classe dopo la lotta di classe. Interview ed. by P. Borgna (Laterza, 2012), 